\title{
19. PALEOPRODUCTIVITY AND CLIMATE VARIATIONS DURING SAPROPEL DEPOSITION IN THE EASTERN MEDITERRANEAN SEA ${ }^{1}$
}

\author{
Liselotte Diester-Haass, ${ }^{2}$ Christian Robert, ${ }^{3}$ Herve Chamley ${ }^{4}$
}

\begin{abstract}
At four sites from the Eastern Mediterranean, three to five sapropel layers and surrounding oxygenated sediments from the late and early Quaternary and Pliocene were investigated by a multidisciplinary approach which included analyses of coarse fraction, carbon and sulfur contents, grain size, and clay-minerals. Clay-mineral associations are comparable at all sites and in all time periods, in all sapropels, and oxygenated sediments. There is no diagenetic alteration of clay minerals in the sapropels.

The relative importance of the different clay species varies with location of the sites and with time. African and European provenance can be distinguished. In the sapropels clay-mineral associations show changes that suggest increased precipitation in Southern Europe (increase in chlorite, illite, and mixed-layer clays) and intensified atmospheric circulation over Northern Africa and the Middle East (increased amounts of palygorskite and sepiolite).

In all sapropels silt-sized particles increase at the expense of clay-sized particles in relation to higher energy of circulation. Sand-sized terrigenous particles have maximum accumulation rates just prior to sapropel deposition.

Export productivity during deposition of oxygenated sediments has been calculated from benthic foraminifer numbers. It is highest just prior to sapropel deposition than above the sapropels. Paleoproductivity decreases from west to east and from the Pliocene to the Quaternary. Values from the late Quaternary $\left(30-60 \mathrm{gC} / \mathrm{m}^{2} \cdot \mathrm{yr}\right)$ are comparable to values obtained from oceanographic measurements (Bethoux, 1989). On top of Eratosthenes Seamount values are much higher $\left(130-360 \mathrm{gC} / \mathrm{m}^{2} \cdot \mathrm{yr}\right)$.

The degree of carbonate dissolution reflects three types of sapropels: (1) nonbioturbated sapropels with excellent carbonate preservation; (2) increase in carbonate dissolution towards the top of the sapropel because of "burning down" phenomena; (3) bioturbated Pliocene sapropels with carbonate dissolution as strong as in surrounding oxygenated sediments.
\end{abstract}

\section{INTRODUCTION}

Sapropels are a major characteristic of Pliocene and Quaternary sediments of the Mediterranean. They are identified mostly by their gray to dark-gray or black color, a consequence of a high content of organic matter. Other features include presence of sulfides and/or sulfates, assemblages of microplankton, and clay minerals somewhat different from those in the adjacent sediment (Chamley, 1971; Cita et al., 1977).

A main objective of Ocean Drilling Program Leg 160 has been to find out which factors lead to the formation of sapropels during the Neogene in the Eastern Mediterranean Sea. Sapropel occurrences are cyclic and correspond to minima in the precession index when perihelion occurs in the northern hemisphere summers (Rossignol-Strick et al., 1982; Rossignol-Strick, 1983, 1985), especially when minima of precession occurs during maxima of eccentricity (Hilgen et al., 1993). Generally, sapropels lag minima of precession by $\sim 3$ k.y.; this lag may correspond to the response time of the Mediterranean environment to the original forcing (Hilgen et al., 1993). However, some differences in the occurrence of sapropels have been observed (Emeis and Shipboard Scientific Party, 1996).

1. Sapropels are more frequent in lower Pliocene sediments than in upper Pliocene and Quaternary deposits where they are often associated in clusters.

2. Early Pliocene sapropels occurred simultaneously over the whole basin, independently of the water depth, whereas intensity of late Pliocene and Quaternary sapropels (as established

${ }^{1}$ Robertson, A.H.F., Emeis, K.-C., Richter, C., and Camerlenghi, A. (Eds.), 1998. Proc. ODP, Sci. Results, 160: College Station, TX (Ocean Drilling Program).

${ }^{2}$ Fachrichtung Geographie, Universität des Saarlandes, 66041 Saarbrücken, Federal Republic of Germany. 0684167360-0001@t-online.de France.

${ }_{3}^{3}$ Centre d'Oceanologie de Marseille, Luminy case 901, 13288 Marseille Cedex 9,

${ }^{4}$ Sedimentologie et Geodynamique, Universite de Lille 1, 59655 Villeneuve d'Ascq Cedex, France. from their content of organic carbon) changes with water depth.

3. Changes in sapropel occurrence seem to take place at $\sim 2.6$ Ma., close to major development of the Arctic ice sheet and associated modification of global climate.

Moreover, several hypotheses for the origin of sapropels are discussed (op. cit.), which focus on two main lines: (1) increase in freshwater input could have resulted in the development of a low-salinity surface-water layer, which reduced deep-water circulation and led to anoxia at the seafloor, and (2) increased productivity, caused by higher nutrient input either by eurasian rivers and the Nile River, or by a reversal of the circulation in the Eastern Mediterranean to an estuarine type (Sarmiento et al.,1988; see lit. review in Rohling, 1994; Van Os et al., 1994; Emeis and Shipboard Scientific Party, 1996).

Although sapropel occurrence seems clearly related to global climate forcing, development and intensity of individual sapropels appear as somewhat dependent of interaction within the climate and ocean system. The aim of the present investigation is: (1) to gather information on sapropels that developed in different areas of the Eastern Mediterranean and at different periods of the Pliocene and Quaternary; (2) to search for general environmental conditions (and local peculiarities) that allowed development of sapropels; and (3) to find support for one or several of the arguments used in the theories for sapropel formation. Four sapropel layers and surrounding oxygenated sediments have been studied in each of four ODP drillholes along a west-east profile in the Eastern Mediterranean. Our multidisciplinary approach includes estimation of paleoproductivity, variations of organic carbon and sulfur, grain size of terrigenous particles, mineralogy of clays, and morphology of clay particles.

\section{MATERIAL AND METHODS}

The sapropel units investigated are from Sites 964, 966, 967, and 969 (for location and water depth see Fig.1 and Table 1). At each site, Pliocene and Quaternary sapropel units of comparable ages (but not 
coeval; Table 2) have been sampled at 2- to $10-\mathrm{cm}$ intervals. The Quaternary sapropels are not affected by bioturbation, whereas Pliocene sapropels are generally bioturbated (only at Site 969 is the late Pliocene sapropel also undisturbed; see core photographs in Emeis, Robertson, Richter, et al., 1996). Burrowing has been marked on figures showing composition of the sand fraction.

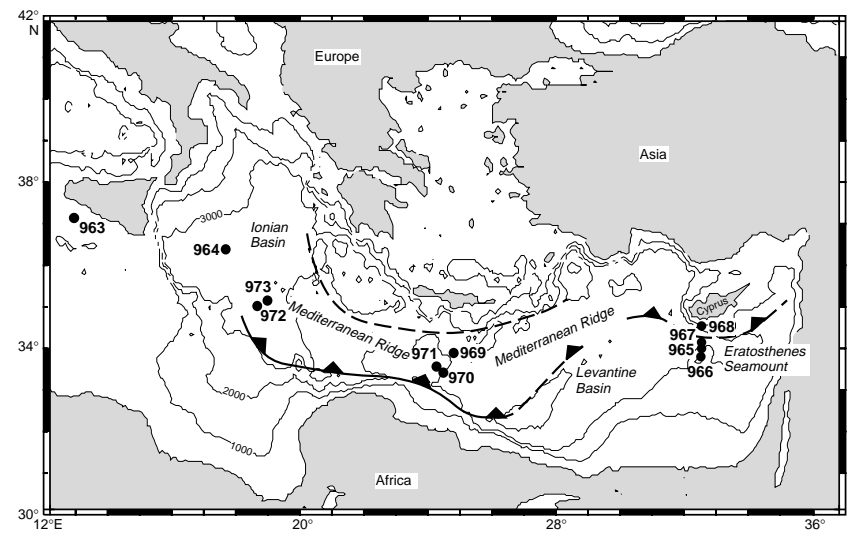

Figure 1. Location of the four sites (Sites 964, 966, 967, and 969) investigated (contours in meters).
A quantitative coarse-fraction analysis has been carried out following the method described in Diester-Haass (1995). Furthermore, in the $>150 \mu \mathrm{m}$ fraction, the number of benthic foraminifers per gram of sediment was counted, and their mass accumulation and export productivity was calculated according to the formula of Herguera and Berger (1991):

$$
\mathrm{PP}=\mathrm{Z}(\mathrm{a}+\mathrm{b} \text { BFAR }) / 100 \times(\mathrm{k}+\mathrm{r} \times \sqrt{\mathrm{Z}}),
$$

where $\mathrm{Z}$ is water depth in meters, and BFAR is the accumulation rate of benthic foraminifers $>150 \mu \mathrm{m}$. Parametrization of the constants a, $\mathrm{b}, \mathrm{k}$, and $\mathrm{r}$ followed that of Herguera and Berger (1991): $\mathrm{a}$ and $\mathrm{b}$ were set to 31 and 1.06 , respectively. These factors describe the relation between the organic flux $(\mathrm{Jz})$ arriving at the seafloor and benthic foraminifer accumulation rates. $\mathrm{k}$ is defined as a function of primary

Table 1. Location of investigated sites.

\begin{tabular}{cccc}
\hline & \multirow{2}{*}{$\begin{array}{c}\text { Water depth } \\
\text { Hole }\end{array}$} & \multicolumn{2}{c}{ Position } \\
\cline { 3 - 4 } & & $\mathrm{N}$ & $\mathrm{E}$ \\
\hline $964 \mathrm{~A}$ & 3770 & $36^{\circ} 15.523^{\prime}$ & $17^{\circ} 44.990^{\prime}$ \\
$966 \mathrm{~A}$ & 1044 & $33^{\circ} 47.799^{\prime}$ & $32^{\circ} 42.095^{\prime}$ \\
$966 \mathrm{C}$ & 1064 & $33^{\circ} 47.779^{\circ}$ & $32^{\circ} 42.089^{\prime}$ \\
$967 \mathrm{~A}$ & 2705 & $34^{\circ} 04.098^{\prime}$ & $32^{\circ} 43.523^{\prime}$ \\
$969 \mathrm{~A}$ & 2320 & $33^{\circ} 50.399^{\prime}$ & $24^{\circ} 53.065^{\prime}$ \\
\hline
\end{tabular}

Table 2. Linear sedimentation rates, dry bulk density, and mass accumulation rates.

\begin{tabular}{|c|c|c|c|c|}
\hline $\begin{array}{l}\text { Core, section, } \\
\text { interval }(\mathrm{cm})\end{array}$ & $\begin{array}{l}\text { Depth } \\
\text { (mbsf) }\end{array}$ & $\begin{array}{c}\text { LSR } \\
\text { (cm/k.y.) }\end{array}$ & $\begin{array}{l}\text { DBD } \\
\left(\mathrm{g} / \mathrm{cm}^{3}\right)\end{array}$ & $\begin{array}{c}\text { MAR } \\
\left(\mathrm{g} / \mathrm{cm}^{2} \cdot \mathrm{k} \cdot \mathrm{y} .\right)\end{array}$ \\
\hline $\begin{array}{c}160-964- \\
2 \mathrm{H}-1,80-82 \\
2 \mathrm{H}-1,85-87 \\
2 \mathrm{H}-1,92-94 \\
2 \mathrm{H}-1,96-98 \\
2 \mathrm{H}-1,100-102 \\
2 \mathrm{H}-1,105-107 \\
2 \mathrm{H}-1,108-110 \\
2 \mathrm{H}-1,112-114 \\
5 \mathrm{H}-1,105-107 \\
5 \mathrm{H}-1,110-112 \\
5 \mathrm{H}-1,115-116 \\
5 \mathrm{H}-1,120-122 \\
5 \mathrm{H}-1,125-127 \\
5 \mathrm{H}-1,130-132 \\
9 \mathrm{H}-5,23-25 \\
9 \mathrm{H}-5,28-30 \\
9 \mathrm{H}-5,31-33 \\
9 \mathrm{H}-5,34-36 \\
9 \mathrm{H}-5,38-40 \\
9 \mathrm{H}-5,41-43 \\
9 \mathrm{H}-5,46-48\end{array}$ & $\begin{array}{l}7.6 \\
7.65 \\
7.72 \\
7.76 \\
7.8 \\
7.85 \\
7.88 \\
7.92 \\
36.35 \\
36.4 \\
35.45 \\
36.5 \\
36.55 \\
36.6 \\
79.53 \\
79.58 \\
79.61 \\
79.64 \\
79.68 \\
79.71 \\
79.76\end{array}$ & $\begin{array}{l}5.23 \\
5.23 \\
5.23 \\
5.23 \\
5.23 \\
5.23 \\
5.23 \\
5.23 \\
3.49 \\
3.49 \\
3.49 \\
3.49 \\
3.49 \\
3.49 \\
1.76 \\
1.76 \\
1.76 \\
1.76 \\
1.76 \\
1.76 \\
1.76\end{array}$ & $\begin{array}{l}0.98 \\
1 \\
1 \\
1.02 \\
1.03 \\
1.04 \\
1.05 \\
1.05 \\
1.16 \\
1.16 \\
1.16 \\
1.16 \\
1.16 \\
1.16 \\
1.27 \\
1.27 \\
1.27 \\
1.27 \\
1.27 \\
1.27 \\
1.27\end{array}$ & $\begin{array}{l}5.13 \\
5.23 \\
5.23 \\
5.33 \\
5.39 \\
5.44 \\
5.49 \\
5.49 \\
4.05 \\
4.05 \\
4.05 \\
4.05 \\
4.05 \\
4.05 \\
2.24 \\
2.24 \\
2.24 \\
2.24 \\
2.24 \\
2.24 \\
2.24\end{array}$ \\
\hline $\begin{array}{l}160-966 \mathrm{~A}- \\
1 \mathrm{H}-3,110-112 \\
1 \mathrm{H}-3,122-124 \\
1 \mathrm{H}-3,127-129 \\
1 \mathrm{H}-3,134-136 \\
1 \mathrm{H}-3,145-147 \\
3 \mathrm{H}-4,110-112 \\
3 \mathrm{H}-4,123-125 \\
3 \mathrm{H}-4,127-129 \\
3 \mathrm{H}-4,130-132 \\
3 \mathrm{H}-4,141-143\end{array}$ & $\begin{array}{l}4.1 \\
4.22 \\
4.27 \\
4.34 \\
4.45 \\
20.9 \\
21.03 \\
21.07 \\
21.1 \\
21.21\end{array}$ & $\begin{array}{l}1.77 \\
1.77 \\
1.77 \\
1.77 \\
1.77 \\
2.99 \\
2.99 \\
2.99 \\
2.99 \\
2.99\end{array}$ & $\begin{array}{l}1.2 \\
1.2 \\
1.2 \\
1.21 \\
1.21 \\
1.13 \\
1.13 \\
1.13 \\
1.13 \\
1.13\end{array}$ & $\begin{array}{l}2.12 \\
2.12 \\
2.12 \\
2.14 \\
2.14 \\
3.38 \\
3.38 \\
3.38 \\
3.38 \\
3.38\end{array}$ \\
\hline $\begin{array}{c}\text { 160-966C- } \\
3 \mathrm{H}-4,31-33 \\
3 \mathrm{H}-4,37-39 \\
3 \mathrm{H}-4,41-43 \\
3 \mathrm{H}-4,47-49 \\
3 \mathrm{H}-4,53-55 \\
3 \mathrm{H}-4,61-63 \\
5 \mathrm{H}-2,0-2 \\
5 \mathrm{H}-2,5-7 \\
5 \mathrm{H}-2,14-16 \\
5 \mathrm{H}-2,16-18 \\
5 \mathrm{H}-2,18-20 \\
5 \mathrm{H}-2,26-28 \\
5 \mathrm{H}-2,30-32 \\
7 \mathrm{H}-5,5-7 \\
7 \mathrm{H}-5,9-11 \\
7 \mathrm{H}-5,18-20 \\
7 \mathrm{H}-5,28-30\end{array}$ & $\begin{array}{l}23.81 \\
23.87 \\
23.91 \\
23.97 \\
24.03 \\
24.11 \\
39.5 \\
39.55 \\
39.64 \\
39.66 \\
39.68 \\
39.76 \\
39.8 \\
63.05 \\
63.09 \\
63.18 \\
63.28\end{array}$ & $\begin{array}{l}2.99 \\
2.99 \\
2.99 \\
2.99 \\
2.99 \\
2.99 \\
1.37 \\
1.37 \\
1.37 \\
1.37 \\
1.37 \\
1.37 \\
1.37 \\
2.86 \\
2.86 \\
2.86 \\
2.86\end{array}$ & $\begin{array}{l}1.12 \\
1.12 \\
1.12 \\
1.12 \\
1.12 \\
1.12 \\
1.13 \\
1.13 \\
1.12 \\
1.12 \\
1.12 \\
1.12 \\
1.11 \\
1.25 \\
1.23 \\
1.22 \\
1.2\end{array}$ & $\begin{array}{l}3.35 \\
3.35 \\
3.35 \\
3.35 \\
3.35 \\
3.35 \\
1.55 \\
1.55 \\
1.53 \\
1.53 \\
1.53 \\
1.53 \\
1.52 \\
3.58 \\
3.52 \\
3.49 \\
3.43\end{array}$ \\
\hline
\end{tabular}

\begin{tabular}{|c|c|c|c|c|}
\hline $\begin{array}{l}\text { Core, section, } \\
\text { interval }(\mathrm{cm})\end{array}$ & $\begin{array}{l}\text { Depth } \\
\text { (mbsf) }\end{array}$ & $\begin{array}{c}\text { LSR } \\
\text { (cm/k.y.) }\end{array}$ & $\begin{array}{c}\text { DBD } \\
\left(\mathrm{g} / \mathrm{cm}^{3}\right)\end{array}$ & $\begin{array}{c}\text { MAR } \\
\left(\mathrm{g} / \mathrm{cm}^{2} \cdot \mathrm{k} \cdot \mathrm{y} .\right)\end{array}$ \\
\hline $7 \mathrm{H}-5,38-40$ & 63.38 & 2.86 & 1.19 & 3.40 \\
\hline $7 \mathrm{H}-5,48-50$ & 63.48 & 2.86 & 1.18 & 3.37 \\
\hline $7 \mathrm{H}-5,58-60$ & 63.58 & 2.86 & 1.16 & 3.32 \\
\hline $7 \mathrm{H}-5,68-70$ & 63.68 & 2.86 & 1.14 & 3.26 \\
\hline \multicolumn{5}{|l|}{ 160-967A- } \\
\hline $1 \mathrm{H}-5,135-137$ & 7.35 & 3.47 & 0.73 & 2.53 \\
\hline $1 \mathrm{H}-5,140-142$ & 7.4 & 3.47 & 0.74 & 2.57 \\
\hline $1 \mathrm{H}-5,148-150$ & 7.48 & 3.47 & 0.75 & 2.60 \\
\hline $1 \mathrm{H}-6,3-5$ & 7.53 & 3.47 & 0.77 & 2.67 \\
\hline $1 \mathrm{H}-6,8-10$ & 7.58 & 3.47 & 0.78 & 2.71 \\
\hline $1 \mathrm{H}-6,13-15$ & 7.63 & 3.47 & 0.79 & 2.74 \\
\hline $1 \mathrm{H}-6.18-20$ & 7.68 & 3.47 & 0.81 & 2.81 \\
\hline $1 \mathrm{H}-6,23-25$ & 7.73 & 3.47 & 0.82 & 2.85 \\
\hline $1 \mathrm{H}-6,28-30$ & 7.78 & 3.47 & 0.84 & 2.91 \\
\hline $5 \mathrm{H}-1,148-150$ & 39.28 & 2.85 & 1.07 & 3.05 \\
\hline $5 \mathrm{H}-2,2-4$ & 39.32 & 2.85 & 1.07 & 3.05 \\
\hline $5 \mathrm{H}-2,10-12$ & 39.4 & 2.85 & 1.07 & 3.47 \\
\hline $5 \mathrm{H}-2,19-21$ & 39.49 & 2.85 & 1.07 & 3.05 \\
\hline $5 \mathrm{H}-2,25-27$ & 39.55 & 2.85 & 1.06 & 3.02 \\
\hline $5 \mathrm{H}-2,34-36$ & 39.64 & 2.85 & 1.06 & 3.02 \\
\hline $5 \mathrm{H}-2,47-49$ & 39.77 & 2.85 & 1.05 & 2.99 \\
\hline $9 \mathrm{H}-4,87-89$ & 81.17 & 2.01 & 1.17 & 2.35 \\
\hline $9 \mathrm{H}-4,95-97$ & 81.25 & 2.01 & 0.84 & 1.69 \\
\hline $9 \mathrm{H}-4,101-103$ & 81.31 & 2.01 & 1.17 & 2.35 \\
\hline $9 \mathrm{H}-4,107-109$ & 81.37 & 2.01 & 1.17 & 2.35 \\
\hline \multicolumn{5}{|l|}{ 160-969A- } \\
\hline $1 \mathrm{H}-5,100-102$ & 7 & 2.93 & 0.96 & 2.81 \\
\hline $1 \mathrm{H}-5,110-112$ & 7.1 & 2.93 & 0.97 & 2.84 \\
\hline $1 \mathrm{H}-5,113-115$ & 7.13 & 2.93 & 0.97 & 2.84 \\
\hline $1 \mathrm{H}-5.118-120$ & 7.18 & 2.93 & 0.98 & 2.87 \\
\hline $1 \mathrm{H}-5,124-126$ & 7.24 & 2.93 & 0.98 & 2.87 \\
\hline $3 \mathrm{H}-6,87-89$ & 25.57 & 1.58 & 1.17 & 1.85 \\
\hline $3 \mathrm{H}-6,94-96$ & 25.64 & 1.58 & 1.16 & 1.83 \\
\hline $3 \mathrm{H}-6,97-99$ & 25.67 & 1.58 & 1.16 & 1.83 \\
\hline $3 \mathrm{H}-6,105-107$ & 25.75 & 1.58 & 1.14 & 1.80 \\
\hline $3 \mathrm{H}-6,114-116$ & 25.84 & 1.58 & 1.14 & 1.80 \\
\hline $7 \mathrm{H}-1,39-41$ & 55.59 & 2.02 & 1.24 & 2.50 \\
\hline $7 \mathrm{H}-1,52-54$ & 55.72 & 2.02 & 1.23 & 2.48 \\
\hline $7 \mathrm{H}-1,58-60$ & 55.78 & 2.02 & 1.22 & 2.46 \\
\hline $7 \mathrm{H}-1,64-66$ & 55.84 & 2.02 & 1.21 & 2.44 \\
\hline $7 \mathrm{H}-1,76-78$ & 55.96 & 2.02 & 1.2 & 2.42 \\
\hline $10 \mathrm{H}-2,140-142$ & 86.6 & 1.89 & 1.31 & 2.48 \\
\hline $10 \mathrm{H}-2,144-146$ & 86.64 & 1.89 & 1.3 & 2.46 \\
\hline $10 \mathrm{H}-2,148-150$ & 86.68 & 1.89 & 1.29 & 2.44 \\
\hline $10 \mathrm{H}-3,3-5$ & 86.73 & 1.89 & 1.28 & 2.42 \\
\hline $10 \mathrm{H}-3,7-9$ & 86.77 & 1.89 & 1.28 & 2.42 \\
\hline $10 \mathrm{H}-3,12-14$ & 86.82 & 1.89 & 1.27 & 2.40 \\
\hline $10 \mathrm{H}-3,16-18$ & 86.86 & 1.89 & 1.26 & 2.38 \\
\hline
\end{tabular}

Note: LSR = Linear sedimentation rate; DBD = dry bulk density; and MAR = mass accumulation rate. 
productivity (PP): $\mathrm{k}=\mathrm{PP} / 4$ (i.e., $\mathrm{k}$ is defined by the unknown that is to be calculated from equation (1), and therefore it had to be obtained by ten iterative steps starting with an arbitrary value of 80 ). Coefficient $r$ was set to 0.5, following Herguera and Berger (1991). Estimated primary productivity $(\mathrm{PP})$ is given in units of gram carbon per square meter and year $\left(\mathrm{g} \mathrm{C} / \mathrm{m}^{2} \cdot \mathrm{yr}\right)$.

The formula of Herguera and Berger (1991) has been established in recent and subrecent sediments based on the observation that benthic foraminifer numbers are linked to surface-water productivity levels. It is assumed that this relation is a fundamental biological principle that is also valid in the past. However, the absolute productivity scale that we have derived by applying the paleoproductivity formula to the benthic abundance record from Mediterranean sediments remains debatable. Several factors, such as changes in temperature and oxygenation of deep waters, or a change in the dependence of benthic foraminifers on food supply may have influenced the abundance pattern of benthic foraminifers (see discussion in DiesterHaass and Zahn, 1996). Therefore, the benthic flux record is used as a monitor of relative paleoproductivity fluctuations.

Sedimentation rates had to be interpolated between biostratigraphic data points provided from nannofossil studies by Di Stefano (Chap. 8, this volume) and Staerker (Chap. 7, this volume). Bulk densities used for calculation of mass accumulation rates are from Emeis, Robertson, Richter, et al. (1996).

Organic carbon and sulfur analyses have been conducted by a Leco 250 CHNS analyzer, after removal of mineral carbon by $\mathrm{HCl}$. Results are given in percentages. Grain-size analyses have been conducted on the carbonate-free $<63$ - $\mu \mathrm{m}$-sediment fraction using a laserdiffusion, Malvern Mastersizer S. Percentages of clay- $(<4 \mu \mathrm{m})$ and silt- $(>4 \mu \mathrm{m})$ sized particles have been calculated, as well as the position of the mode of the distribution curve (in micrometers). Claymineral analyses have been conducted on carbonate-free, $<2-\mu \mathrm{m}$ sediment-sized particles (separated by decantation), using a Philips Xray diffractometer equipped with a $\mathrm{Cu}$-radiation source. Three analyses were run: (1) untreated sample, (2) glycolated sample, and (3) sample heated for $2 \mathrm{hr}$ at $490^{\circ} \mathrm{C}$. Semiquantitative evaluations are based on the peak heights and areas. The clay indices have been obtained from the ratios of the 001 smectite, palygorskite, illite, and kaolinite diffraction peak heights of the glycolated samples. Some samples have been selected for observation of the morphology of clay particles. For this, $<2-\mu \mathrm{m}$ particles were scattered into a solution of tert-butylamine, and then a drop of the suspension was deposited and evaporated on a copper grid. Observations were made using a Philips transmission electron microscope.

\section{RESULTS}

Contents of organic carbon vary from $0.13 \%$ to $8.02 \%$, with one noticeable exception in Core 160-969A-7H south of Crete, where a sapropel of early Pliocene age contains up to $25.92 \%$ organic carbon (Fig. 2). Concentrations of sulfur vary from $0 \%$ to $3.20 \%$; maximum values of both organic carbon and sulfur are recorded in the same level. Sediment units that show a gray color and have organic carbon contents above $1 \%$ are identified as sapropels. There is a relatively good correlation between abundance of organic carbon and sulfur $(\mathrm{r}$ $=0.84$ ) when sapropels and adjacent oxygenated sediments are considered together; in some cases (Core $1 \mathrm{H}$ at Hole 966A), an increase in sulfur leads the increase in organic carbon. However, inside the sapropels, organic carbon and sulfur do not covary significantly $(r=$ $0.25)$ : highest contents of both elements sometimes coincide and sometimes alternate, or percentages show random variations (Fig. 2). No relation has been evidenced among the abundance of organic carbon and sulfur, the location of the drill sites in the Eastern Mediterranean, or the stratigraphic position of the sapropel layers.

The linear sedimentation rates, dry bulk densities, and calculated mass accumulation rates are given in Table 2. Percentages of the sand fraction investigated reach values of up to $30 \%$ (Figs. 3A-6A). The

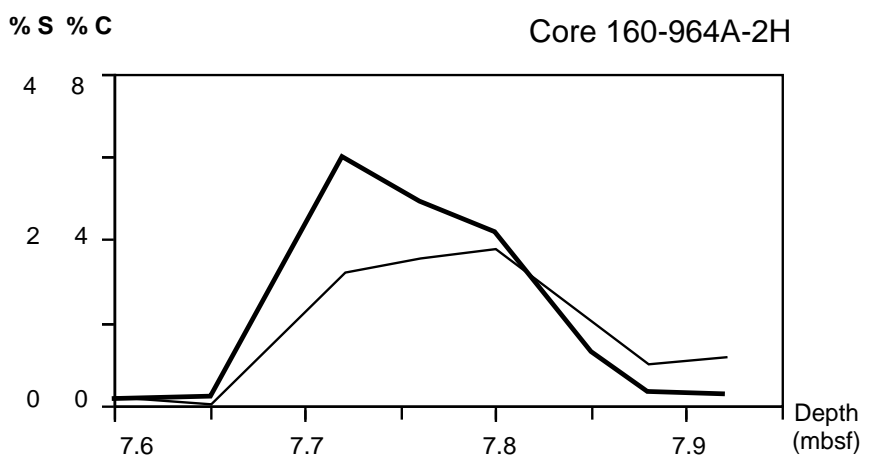

Core 160-969A-7H

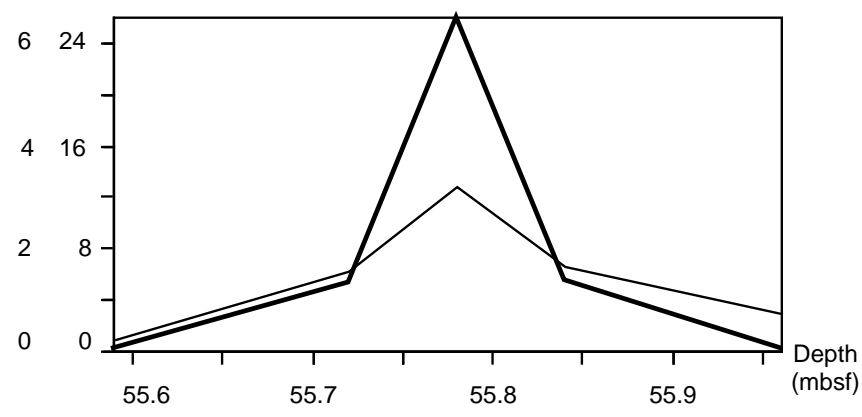

Core $160-966 \mathrm{C}-7 \mathrm{H}$

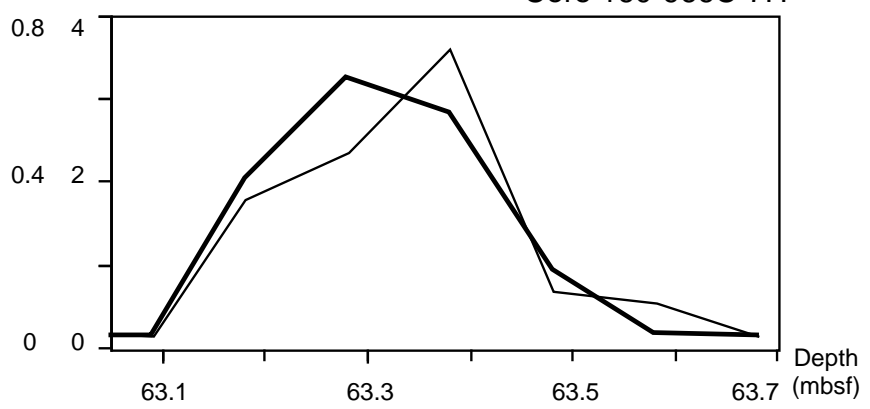

Core 160-967A-1H

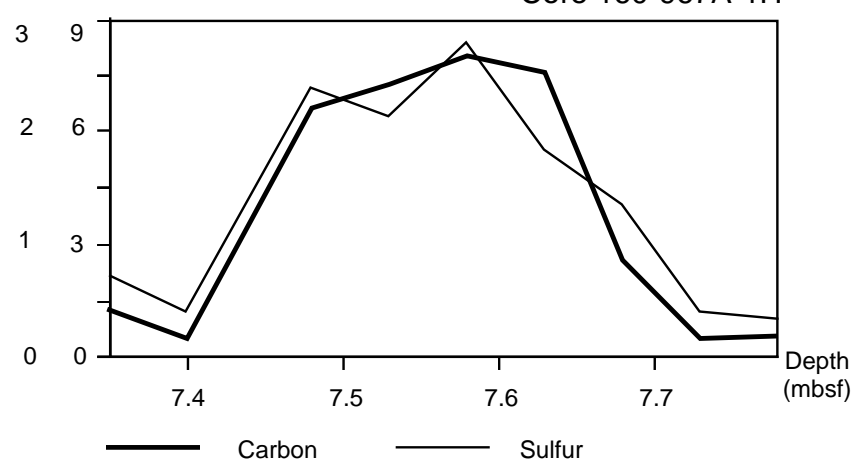

Figure 2. Organic carbon and sulfur content of sapropels and adjacent sediments in the Ionian Basin (Core 160-964A-2H) on the Mediterranean Ridge (Core 160-969A-7H) and on the Eratosthenes Seamount (Cores 160-966C$7 \mathrm{H}$ and $160-967 \mathrm{~A}-1 \mathrm{H})$. Sapropels are defined as sediments where content of organic carbon exceeds $1 \%$. 
A Site 964: \% sand fraction

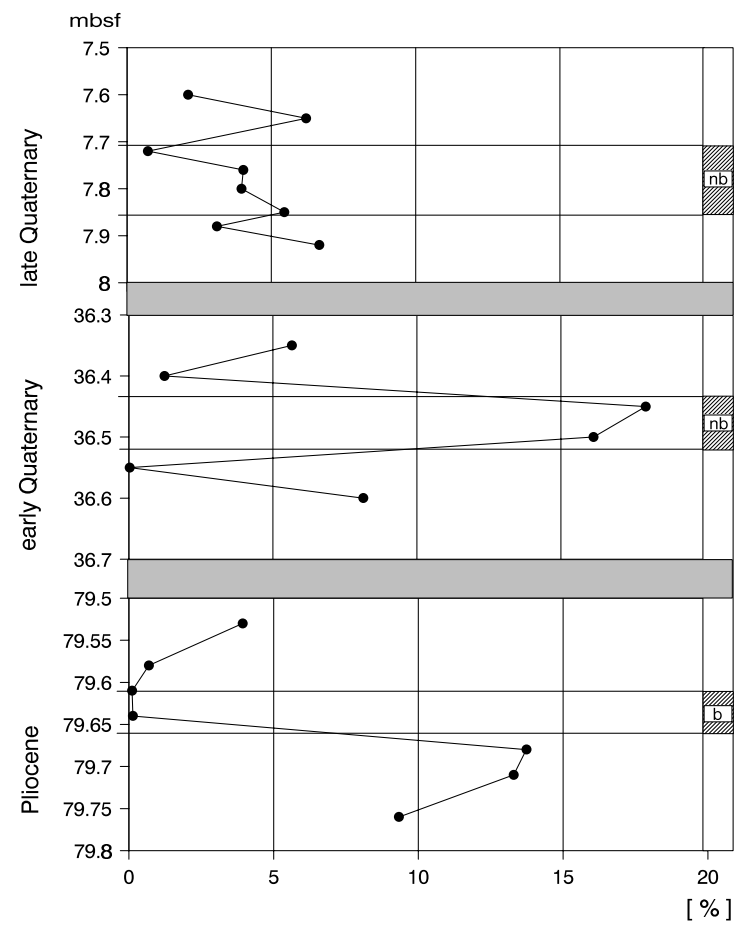

C

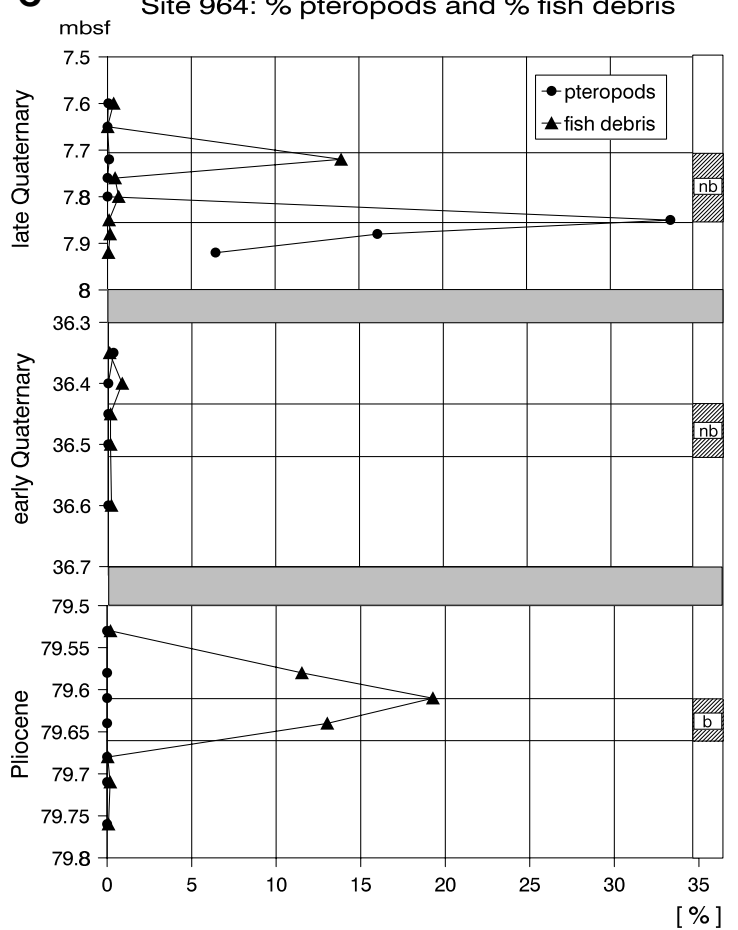

B

Site 964: \% benthic and \% planktic foraminifers

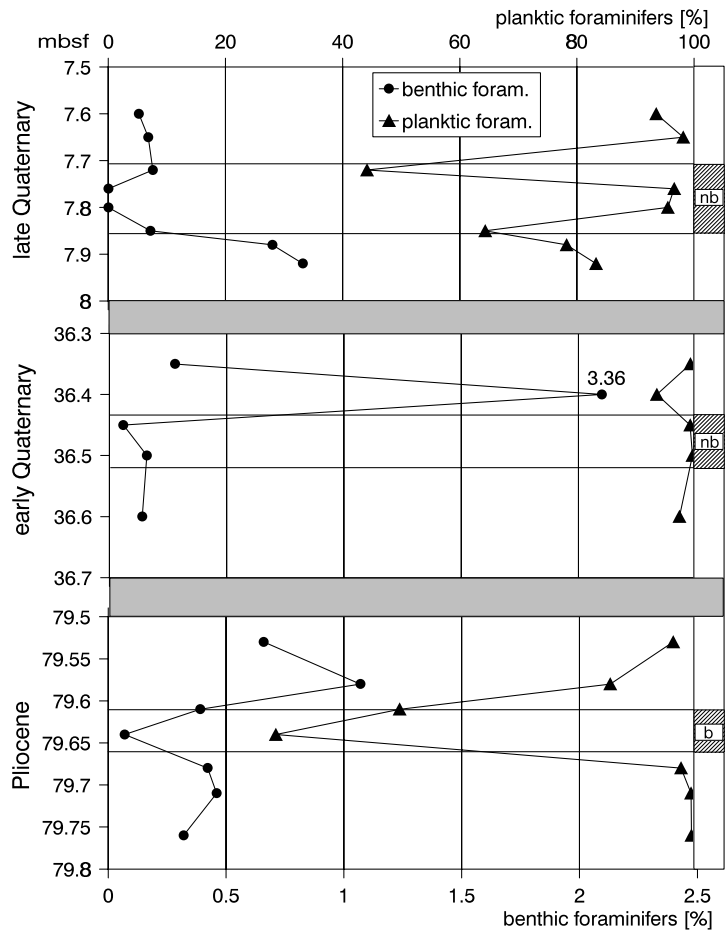

D Site 964: \% terrigenous material and \% pyrite

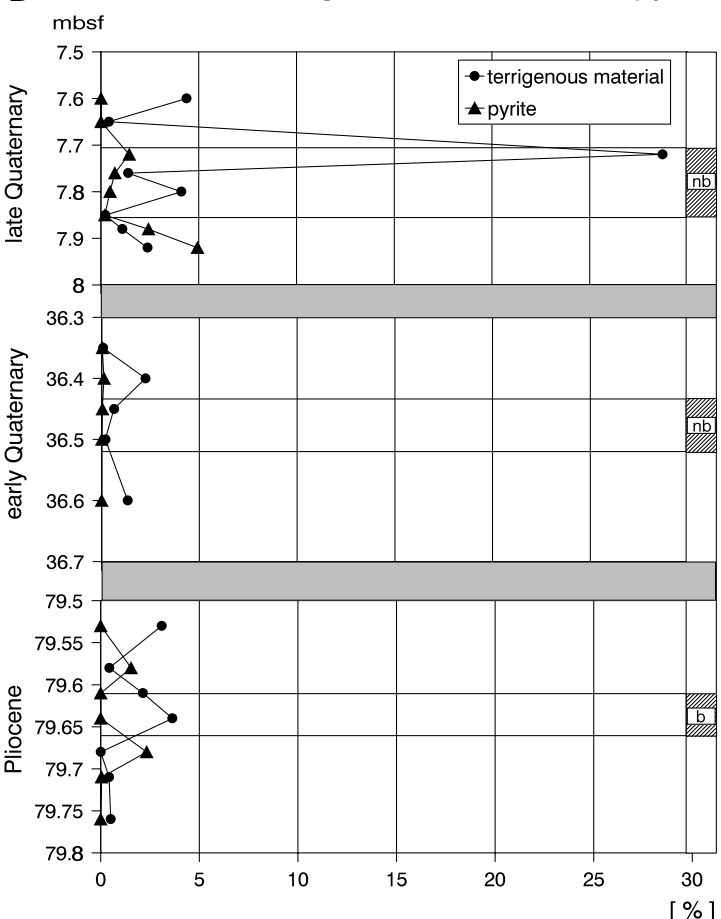

Figure 3. Results of coarse-fraction analysis of sediments from Site 964 . Gray signature on right side $=$ sapropel; nb $=$ nonbioturbated; $b=$ bioturbated (information from core photographs in Emeis, Robertson, Richter, et al., 1966). A. Percent sand fraction. B. Percent benthic and percent planktic foraminifers of sand fraction. C. Percent pteropods and percent fish debris of sand fraction. D. Percent terrigenous matter and percent pyrite of sand fraction. (Continued on next page.) 
E Site 964: Accumulation rate of benthic and planktic foraminifers

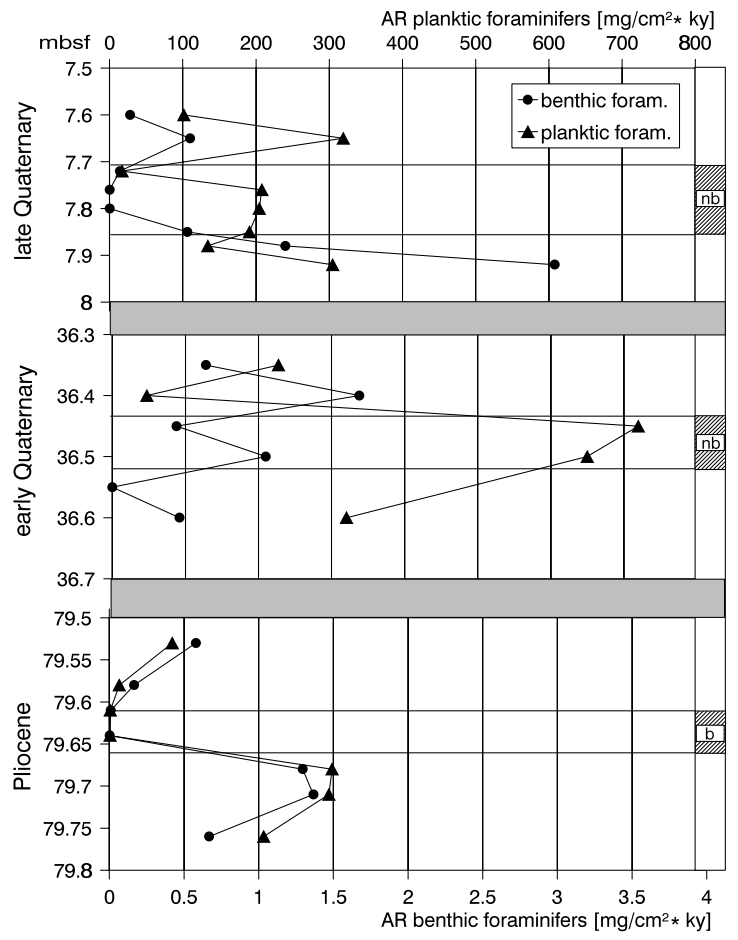

G Site 964: Accumulation rate, terrigenous material

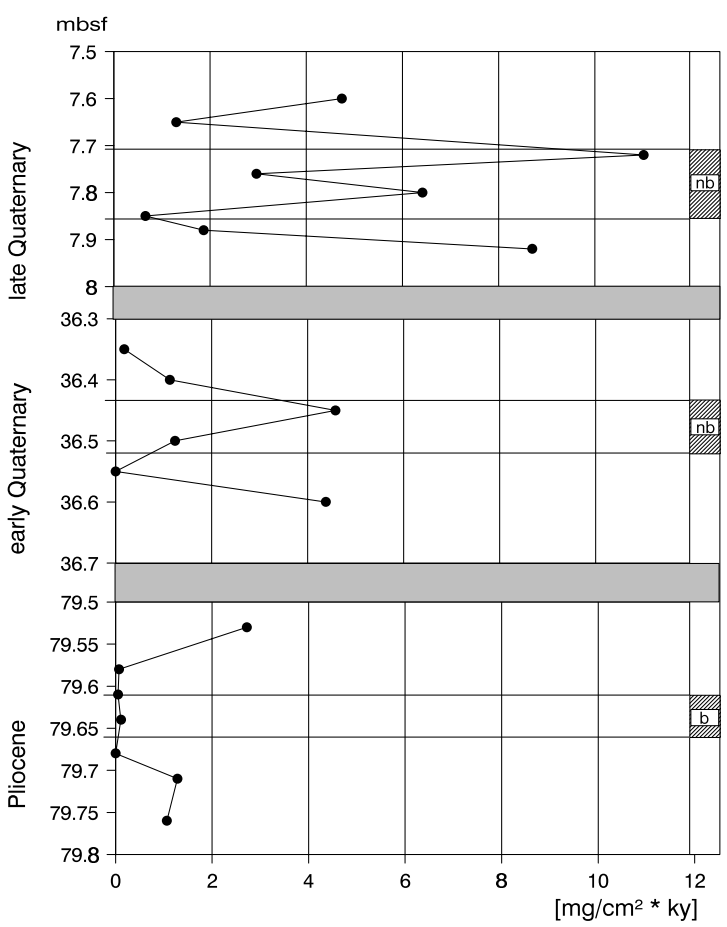

F Site 964: Accumulation rate of echinoids, ostracods, and molluscs

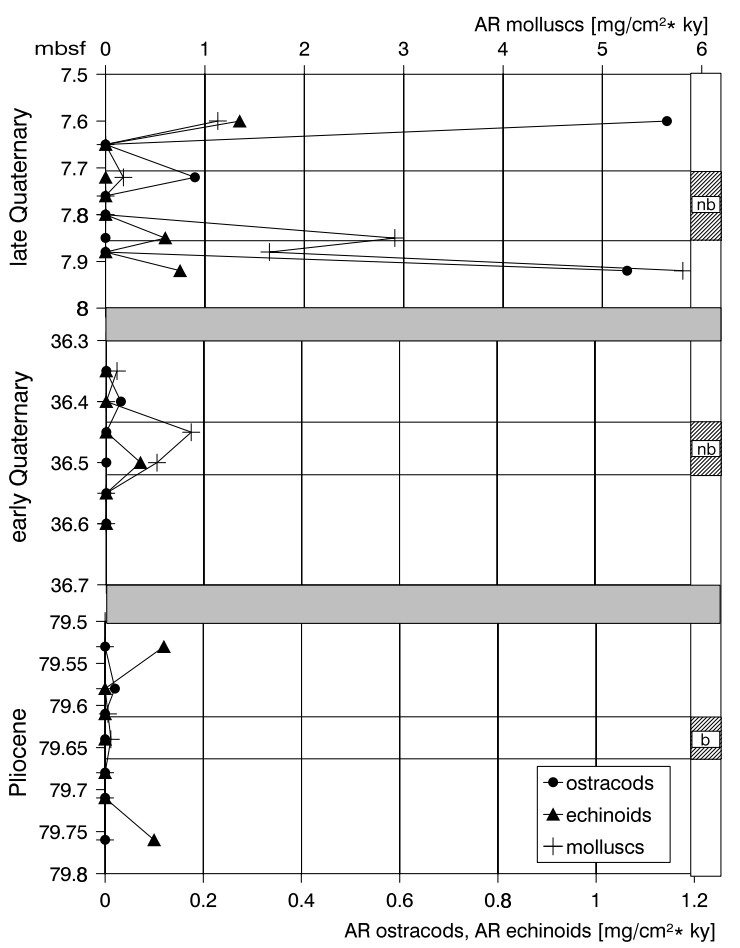

H

Site 964: Carbonate dissolution

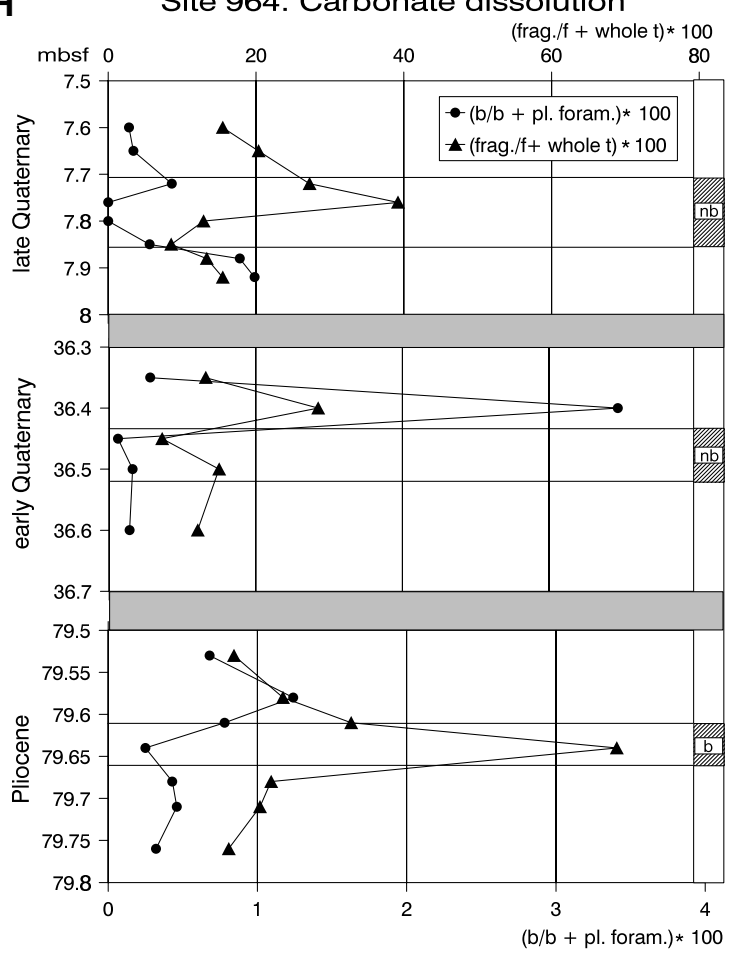

Figure 3 (continued). E. Accumulation rate of benthic and planktic foraminifers. F. Accumulation rate of echinoids, ostracods, and molluscs. G. Accumulation rate of sand-sized, terrigenous material. H. Carbonate dissolution, shown by means of benthic/planktic foraminifer ratios and fragmentation of planktic foraminifers (see text for details). (Continued on next page). 
I

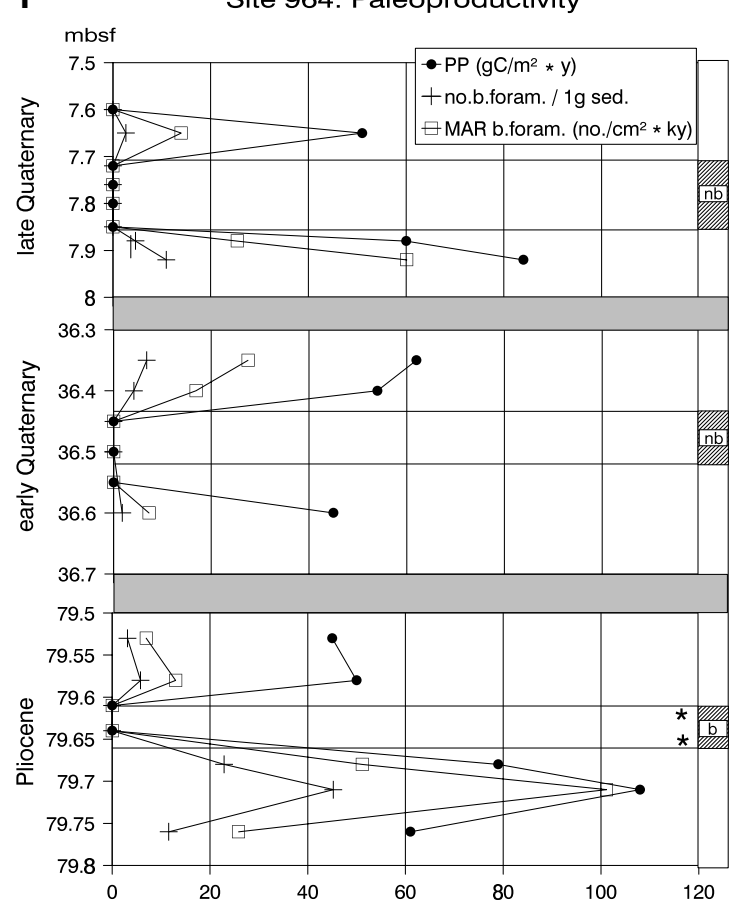

Figure 3 (continued). I. Paleoproductivity (PP), calculated after the formula of Herguera and Berger (1991) from benthic foraminifer numbers in $1 \mathrm{~g}$ of sediment (no.b.foram./1 g sed.) and their mass accumulation rates (MAR; b.foram. $\left[\right.$ no. $\left.\left./ \mathrm{cm}^{2} \cdot \mathrm{k} . \mathrm{y}.\right]\right)$. Star $=$ occurrence of radiolaria.

composition of the sand fraction (Figs. 3B, 3C, 3D through 6B, 6C, 6D) shows planktic and benthic foraminifers as main components, in addition to pteropods, fish debris, terrigenous matter, and pyrite. Minor components, such as radiolarians, echinoids, ostracods, and larval mollusk shells, are shown only in the accumulation rate curves (Figs. 3-6G). Planktic foraminifers form $>95 \%$ of the sand fraction at the deepest location, Site 964 , and $70 \%$ at the shallowest location, Site 966.

Benthic foraminifer percentages (Figs. 3B-6B) increase with decreasing water depth of sites from $<1 \%$ at Site 964 to up to $25 \%$ at Site 966. In general, percent values are zero or close to zero in the Quaternary-age sapropels, but in the Pliocene bioturbated sapropels, they increase and may be similar to those of the surrounding oxygenated sediments.

Pteropods (Figs. 3C-6C) occur only in the late Quaternary at the transition from oxygenated to sapropel sediments, with percentages up to $30 \%$ at Sites 964 and 969, 45\% at Site 967, and 20\% at Site 966.

Fish debris is a minor component with maxima in sapropels (Figs. 3C-6C). Radiolaria have been found at Sites 967 and 964 in sapropels (Figs. 3J and 5J).

The percentage of terrigenous material, mainly quartz, mica, and some other minerals, is in general between $0.5 \%$ and $3 \%$ of the sand fraction, with some exceptions at Sites 964 and 969 (Figs. 3D-6D). Percentages of terrigenous matter are higher just below than above the sapropels at Sites 967 and 966 and in the Quaternary-age unit at Site 969. At Site 964, however, and in the Pliocene-age sediments at Site 969, highest values are in the sapropels.

Pyrite percentages (Figs. 3D-6D) are in general $0 \%-5 \%$, with two exceptions. At Site 967 , the uppermost sample has 50\% pyrite, and in the early Quaternary and Pliocene sediments at Site 969, pyrite increases up to $20 \%$. In 10 of 15 investigated units, pyrite content is highest below the sapropel. Fecal pellets at Site 966 form 5\%-10\% of the sand fraction in and above the bioturbated sapropel (Fig.6D).

Accumulation rates of several components have been calculated to compare fluxes at the four sites and in the 3-4 intervals. We assumed constant sedimentation rates between biostratigraphic boundaries. Accumulation rates of planktonic foraminifers show a wide range between 50 and $600 \mathrm{mg} / \mathrm{cm}^{2} \cdot \mathrm{k} . \mathrm{y}$., but most values are between 50 and $300 \mathrm{mg} / \mathrm{m}^{2} \cdot \mathrm{yr}$ (Figs. 3E-6E). In eight of 15 units they are highest at the bottom of sapropels and decrease upwards. Benthic foraminifer accumulation rates show the well-known decrease with increasing water depth from up to 40 at Site 966 to up to $8 \mathrm{mg} / \mathrm{cm}^{2} \cdot \mathrm{k}$.y. at Site $967,0.1-3 \mathrm{mg} / \mathrm{cm}^{2} \cdot \mathrm{k} . \mathrm{y}$. at Site 969 , and up to $2 \mathrm{mg} / \mathrm{cm}^{2} \cdot \mathrm{k} . \mathrm{y}$. at Site 964 (Figs. 3E-6E). Minimum values are in sapropels. Late Quaternary sapropels are barren, or nearly barren, of benthic foraminifers, whereas in the Pliocene sapropels, which have been bioturbated, accumulation rates of benthic foraminifers increase.

Accumulation rates of ostracods are very low at the deeper sites $\left(<0.8 \mathrm{mg} / \mathrm{cm}^{2} \cdot \mathrm{k}\right.$.y.) and higher (up to $2 \mathrm{mg} / \mathrm{cm}^{2} \cdot \mathrm{k} . \mathrm{y}$.) at the shallower Site 966 , where maxima are just below the sapropels. In the sapropels there are no ostracods (Figs. 3F-6F).

Echinoid accumulation rates (Figs. 3F-6F) show an increase with decreasing water depth from 0.1 at Site 964 to up to $5 \mathrm{mg} / \mathrm{cm}^{2} \cdot \mathrm{k} . \mathrm{y}$. at Site 966. At Sites 966 and 967, echinoid maxima precede the sapropel deposition. The echinoid maximum at Site 969, of late Pliocene age, is simultaneous to the maximum of terrigenous deposition during sapropel formation.

Under the term molluscs we include small calcareous shells of planktic larval stages of molluscs. The accumulation rates of molluscs are $<3 \mathrm{mg} / \mathrm{cm}^{2} \cdot \mathrm{k} . \mathrm{y}$. at the deeper sites and increase up to $10 \mathrm{mg} /$ $\mathrm{cm}^{2} \cdot \mathrm{k} . \mathrm{y}$. at Site 966 in the sediments of Quaternary age, and they decrease to $0 \mathrm{mg} / \mathrm{cm}^{2} \cdot \mathrm{k}$.y. in the Pliocene sediments (Figs. 3F-6F).

Opaline skeletons of radiolaria have been found only at Site 967 (up to $10 \mathrm{mg} / \mathrm{cm}^{2} \cdot \mathrm{k} . \mathrm{y}$. in the late Quaternary and $<0.5 \mathrm{mg} / \mathrm{cm}^{2} \cdot \mathrm{k} . \mathrm{y}$. in the early Quaternary sapropel), as well as in the Pliocene sapropel of Site 964 (Figs. 3I and 5I).

Accumulation rates of $>63-\mu \mathrm{m}$-sized terrigenous material are within the same order of magnitude at the four sites between $<1$ and $\sim 10 \mathrm{mg} / \mathrm{cm}^{2} \cdot \mathrm{k}$.y. At Sites 967 and 966 , maxima occur just before sapropel deposition. At Site 969, this distribution is found in both the early and late Quaternary. In the Pliocene, however, maxima in terrigenous matter are during sapropel deposition at Site 969 (Figs. 3G6G). At Site 964 there is no clear relation between sapropel and accumulation rate of terrigenous matter.

Benthic/planktic foraminifer ratios (calculated as [\% benthics / $\%$ benthics $+\%$ planktics $] \times 100)$ and fragmentation of planktic foraminifers (calculated as [\% fragments $/ \%$ fragments $+\%$ whole tests] $\times 100$ ) are considered to be good carbonate-dissolution indices (Berger, 1976). Both parameters are shown in Figs. 3H-6H. In the sapropels, the benthic/planktic ratio is no dissolution index, because anoxia prevented benthic life. In the oxygenated sediments, the benthic/planktic foraminifer ratio increases with decreasing water depth from $<1$ at Site 964 to $<5$ at Sites 969 and 967 and up to 15 (in the Pliocene up to 28) at Site 966. Fragmentation of planktic foraminifers varies between $<10 \%$ and up to $55 \%$ fragments, with lowest values in sapropels of Quaternary age, whereas they increase in the bioturbated sapropels of Pliocene age. In seven of 15 sapropels, fragmentation is lowest in the lower part of the sapropels and increases to maximum values in the uppermost part of the sapropels or in the lowermost section of the overlying oxygenated sediments.

Benthic foraminifer numbers per gram of sediment and their mass accumulation rates in no./ $/ \mathrm{cm}^{2} \cdot \mathrm{k} . \mathrm{y}$. are shown in Figures 3I-6I. Paleoproductivity calculations (Figs. 3I-6I) have been made in all samples, although they are not significant in the anoxic layers where benthic life is reduced or disappeared. In Quaternary, nonbioturbated sapropels, benthic foraminifer accumulation rates are zero, because no benthic foraminifers have lived, but in Pliocene bioturbated 
A

Site 969: \% sand fraction

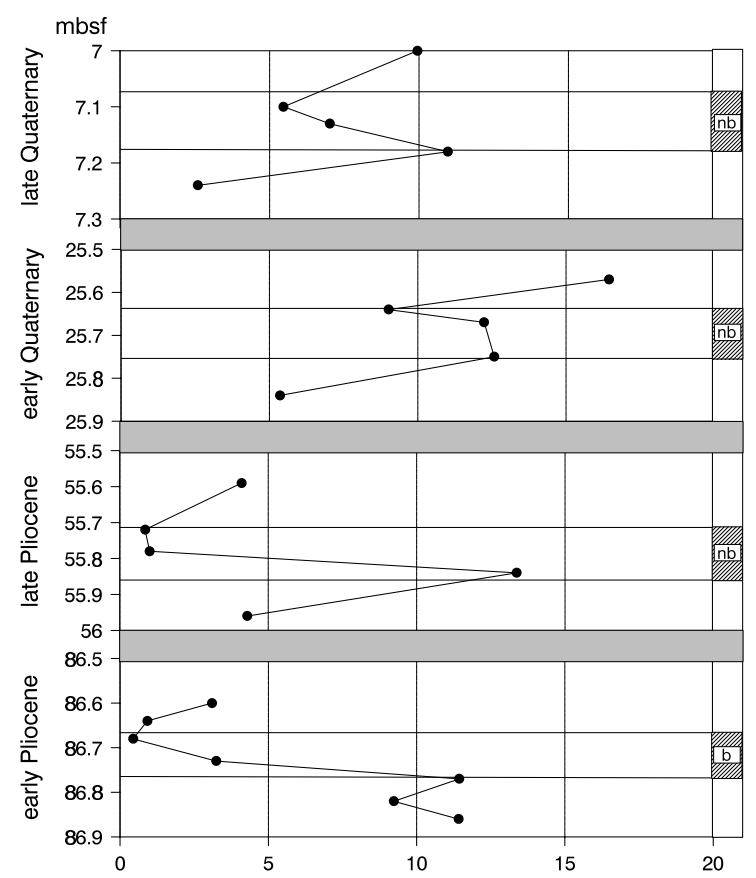

[\%]
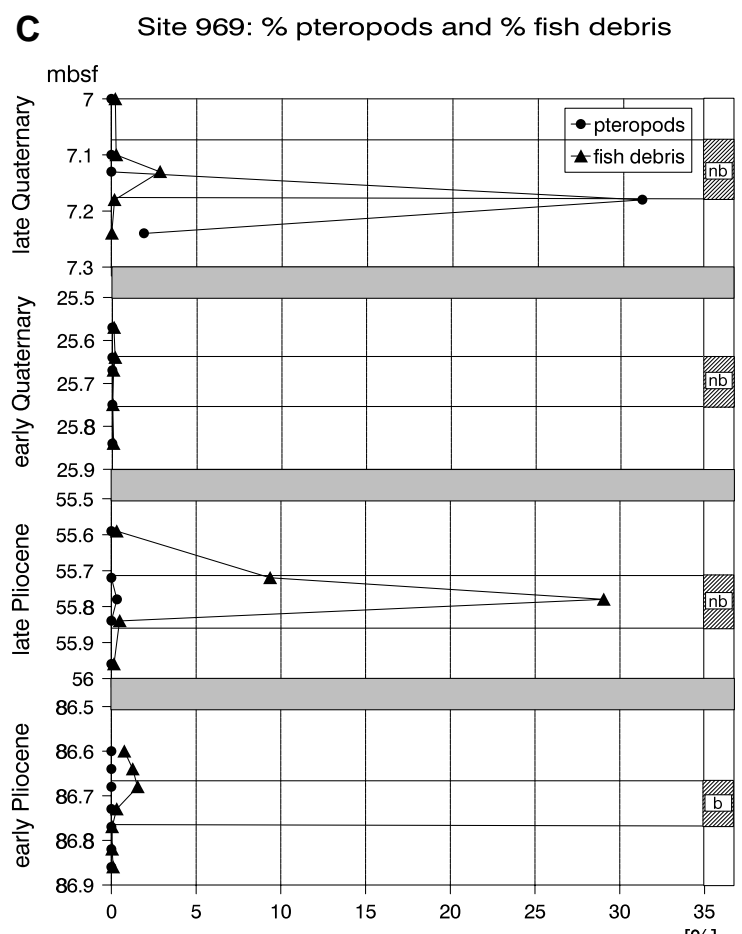

B Site 969: \% benthic and \% planktic foraminifers

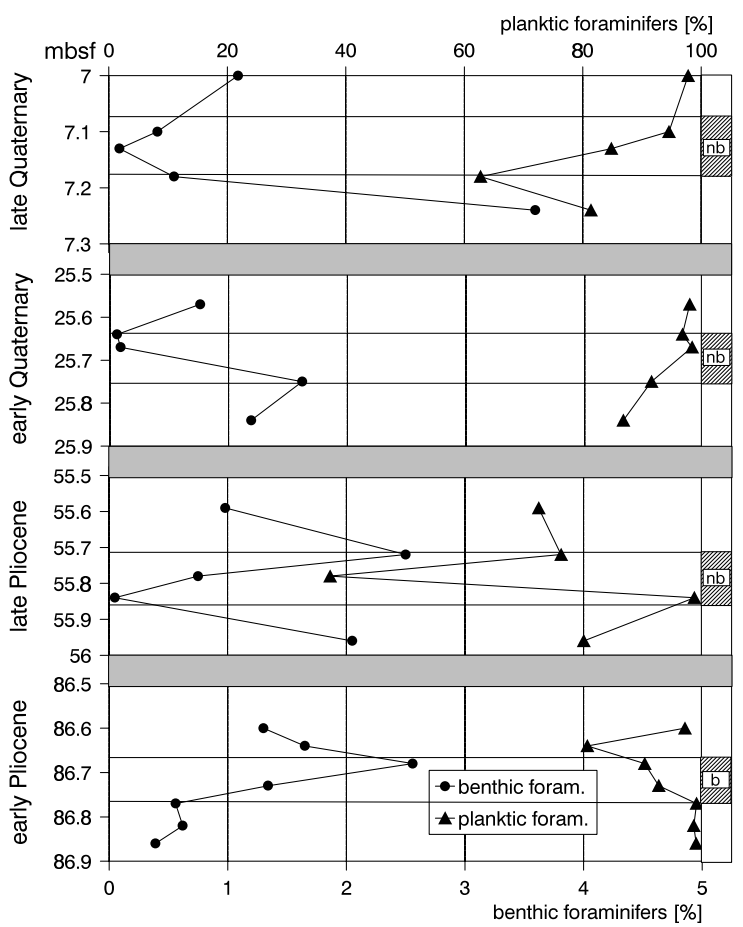

D Site 969: \% terrigenous material and \% pyrite

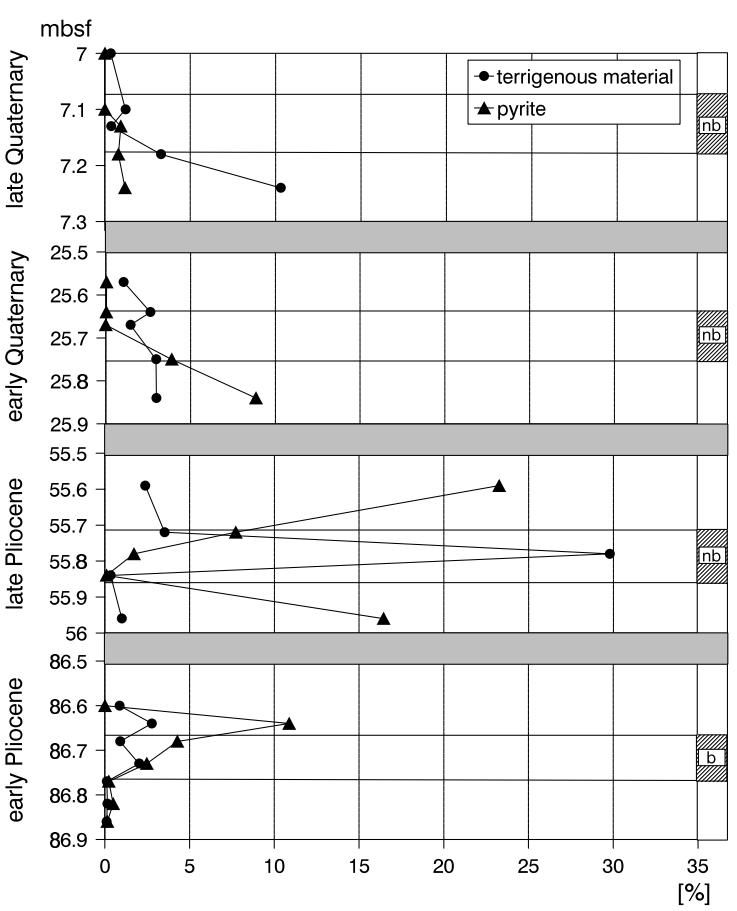

Figure 4. Results of coarse-fraction analysis of sediments from Site 969. Gray signature on right side $=$ sapropel; $n b=$ nonbioturbated; $b=$ bioturbated (information from core photographs in Emeis, Robertson, Richter, et al., 1966). A. Percent sand fraction. B. Percent benthic and percent planktic foraminifers of sand fraction. C. Percent pteropods and percent fish debris of sand fraction. D. Percent terrigenous matter and percent pyrite of sand fraction. (Continued on next page.) 
E Site 969: Accumulation rate of benthic and planktic foraminifers

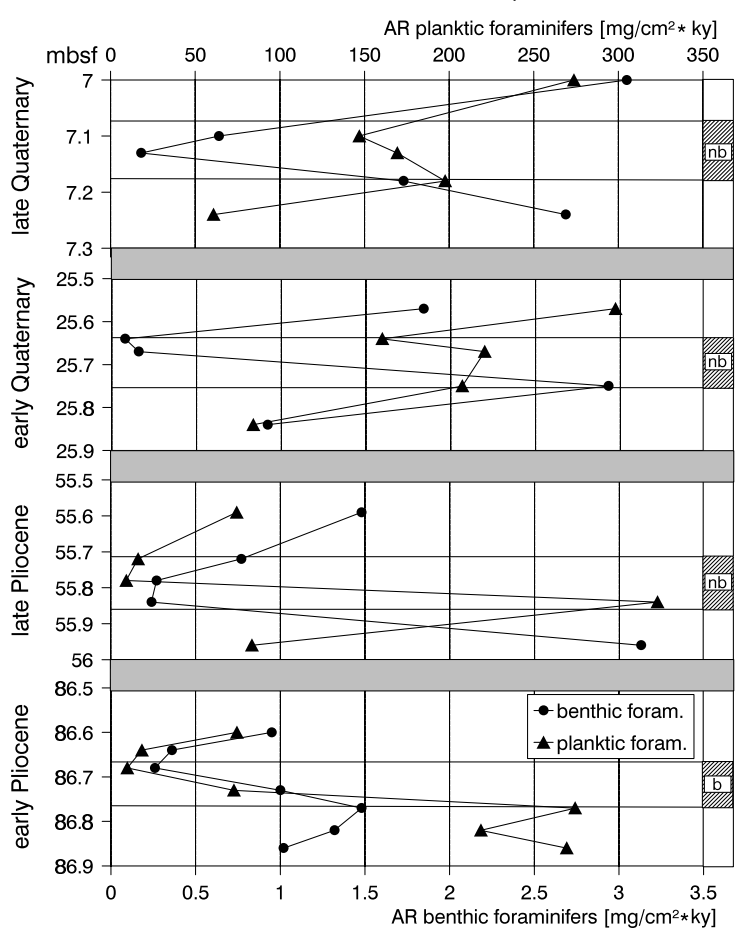

G Site 969: Accumulation rate terrigenous material

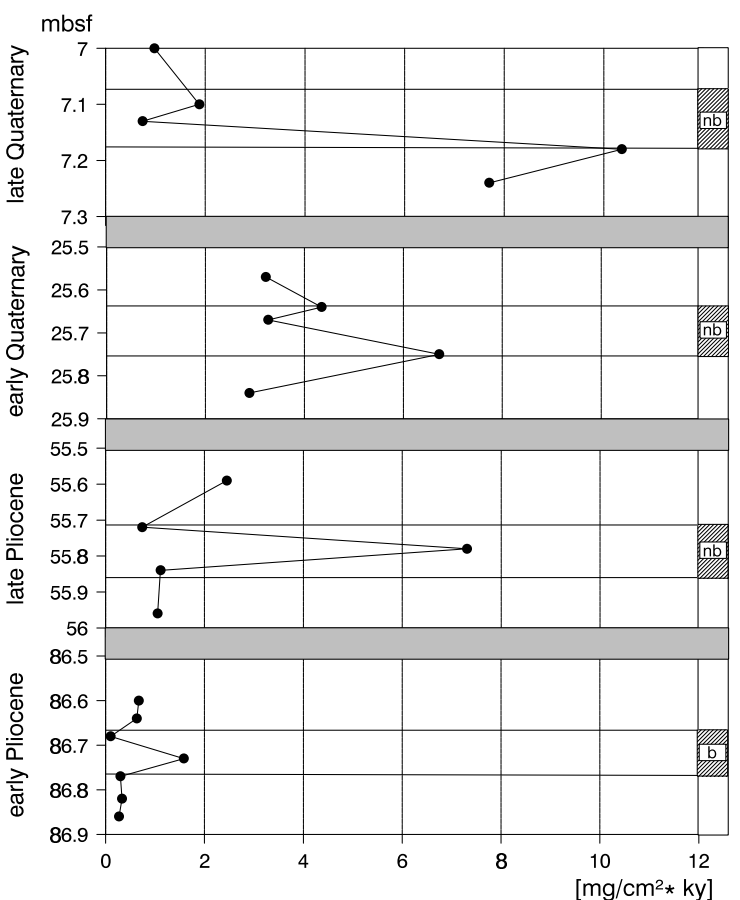

F Site 969: Accumulation rate of echinoids, ostracods and

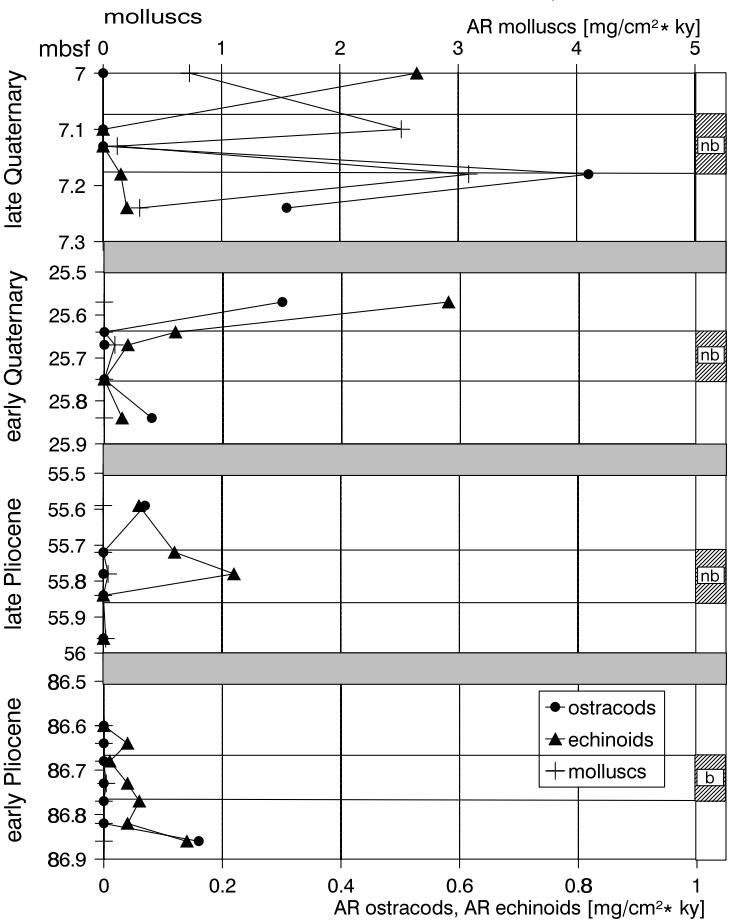

H

Site 969: Carbonate dissolution

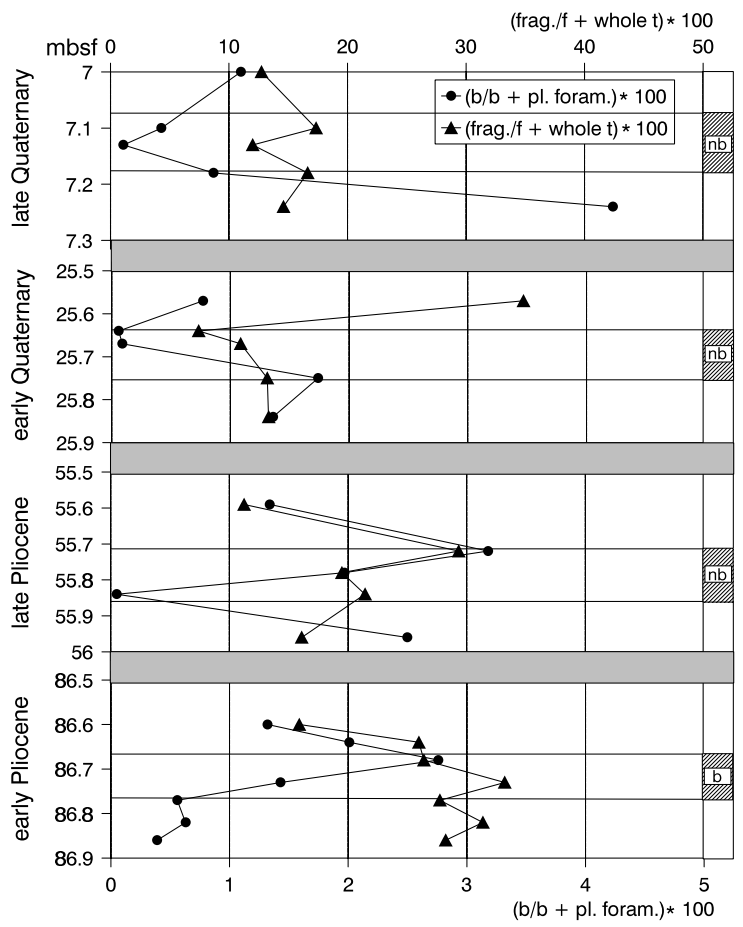

Figure 4 (continued). E. Accumulation rate of benthic and planktic foraminifers. F. Accumulation rate of echinoids, ostracods, and molluscs. G. Accumulation rate of sand-sized, terrigenous material. H. Carbonate dissolution, shown by means of benthic/planktic foraminifer ratios and fragmentation of planktic foraminifers (see text for details). (Continued on next page.) 


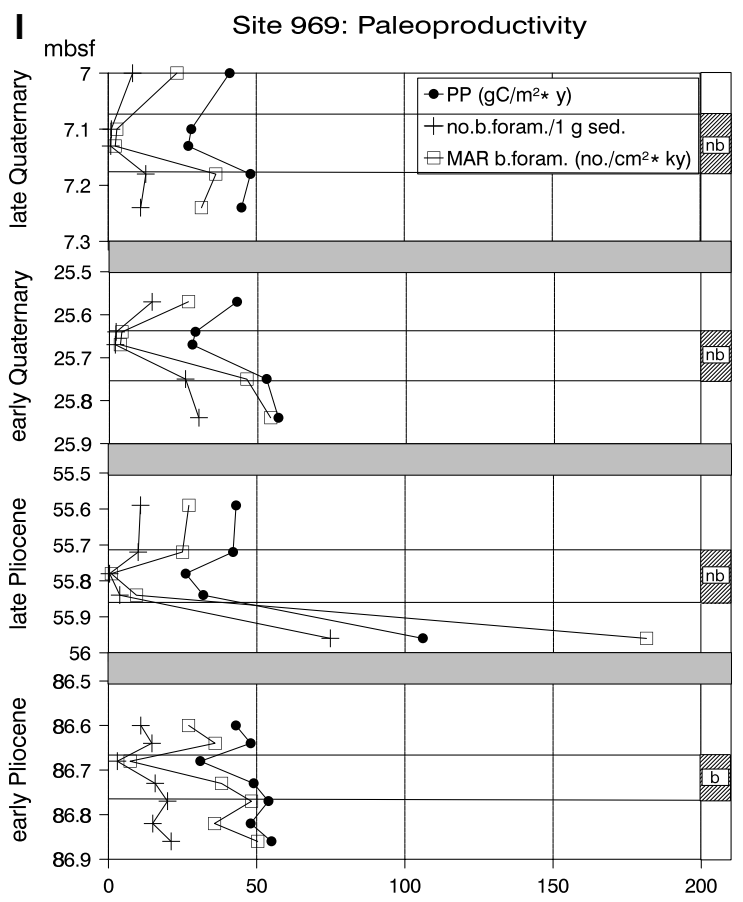

Figure 4 (continued). I. Paleoproductivity (PP), calculated after the formula of Herguera and Berger (1991) from benthic foraminifer numbers in $1 \mathrm{~g}$ of sediment (no.b.foram./1 g sed.) and their mass accumulation rates (MAR; b.foram. [no. $\left.\left./ \mathrm{cm}^{2} \cdot \mathrm{k} . \mathrm{y}.\right]\right)$.

sapropels, benthic foraminifer accumulation rates are similar or even higher in sapropels than in the surrounding sediments.

In the oxygenated sediments paleoproductivity is highest on the Eratosthenes Seamount, Site 966 , with $130-360 \mathrm{gC} / \mathrm{m}^{2} \cdot \mathrm{yr}$. At the other sites, values vary between 30 and $60(80) \mathrm{gC} / \mathrm{m}^{2} \cdot \mathrm{yr}$ in the late Quaternary and up to $110(964)$ and $180(967) \mathrm{gC} / \mathrm{m}^{2} \cdot \mathrm{yr}$ in the early Quaternary and Pliocene. In the late Quaternary, paleoproductivity decreases from west to east (Site 964: $50-80 \mathrm{gC} / \mathrm{m}^{2} \cdot \mathrm{yr}$; Site 969: 40$50 \mathrm{gC} / \mathrm{m}^{2} \cdot \mathrm{yr}$; Site 967: 35-50 gC/m².yr). At Sites 964, 967, and 966, paleoproductivity in the oxygenated sediments increases with time. In 11 of 15 investigated units, paleoproductivity is higher in the oxygenated sediments just before sapropel deposition than in the overlying oxygenated sediments.

The grain-size analysis of the terrigenous fraction $<63 \mu \mathrm{m}$ show that percentages of silt $(4-63 \mu \mathrm{m})$ and clay (below $4 \mu \mathrm{m})$ are roughly equivalent in sediments overlying and underlying the sapropels. The mean percentage of silt increases in the sapropels (65\%), whereas the abundance of the clay decreases (Fig. 7). This is supported by the variation of the mode of the particle distribution from a mean value of $3.4 \mu \mathrm{m}$ in oxidized sediments to a mean value of $7.6 \mu \mathrm{m}$ in the sapropels (Fig. 7). A good correlation $(r=0.90)$ has been evidenced between abundances of silt and organic carbon in sapropels and adjacent oxidized sediments. Detailed analysis also shows that increased and decreased values of organic carbon are associated with similar trends of the silt content, for example, in Core 160-966C-7H (Fig. 8). No relation has been observed between grain-size variations and the distribution of pyrite because (1) maxima of pyrite in the sand fraction do not correlate with increases in grain size; and (2) only trace amounts of pyrite have been episodically found in the fine fraction of the sapropels where they do not coincide with maxima of grain size. No relation has been found between the grain size of the terrigenous fraction and the stratigraphic position of the sapropels, or the location of the site in the Eastern Mediterranean.
Clay minerals include chlorite, illite, random mixed-layer clays, smectite, kaolinite, palygorskite, and sepiolite. Average values of the entire Eastern Mediterranean show very similar clay-mineral associations in the sapropels and adjacent sediments (Fig. 9). The sapropels are not characterized by a specific mineralogy, only minor increases of mixed-layers and palygorskite, and decreases of kaolinite are observed.

The mineralogy of clays varies mostly according to the position of the sites in the Eastern Mediterranean (Table 3). The dominant clay minerals are illite, smectite, and kaolinite in the Ionian Basin (Hole 964A); illite, smectite, kaolinite, and palygorskite on the Mediterranean Ridge (Hole 969A); and smectite and kaolinite on the Eratosthenes Seamount (Holes 966A, 966C, and 967A). The only noticeable difference among the sites on the Eratosthenes Seamount is a higher content of smectite and lower content of kaolinite at the deeper Site 967.

At any given site, the clay-mineral association remains the same for the entire Pliocene and Quaternary section, but the proportion of most clay species vary in relation to the age of the sediment.

1. In the Ionian Basin (ODP Site 964), average contents of kaolinite decrease from $37.2 \%$ in lower Pliocene sediments to $30 \%$ in the Quaternary, and those of illite and palygorskite decrease from $25 \%$ to $20.75 \%$ and from $10.8 \%$ to $5.25 \%$, respectively. Mean smectite contents increase from $18.5 \%$ to $28.7 \%$.

2. On the Mediterranean Ridge south of Crete (Site 969), decreases in the mean abundance of smectite $(32 \%-28 \%)$ and kaolinite $(23.4 \%-17.6 \%)$ are observed in the sediments from the early Pliocene to the Quaternary, whereas the mean content of illite increases from $18 \%$ to $23 \%$.

3. On the Eratosthenes Seamount south of Cyprus, roughly similar evolutions are observed at Sites 966 and 967. At the shallowest Site 966, average percentages of kaolinite decrease from $32 \%$ (early Pliocene) to $21 \%$ (Quaternary), whereas smectite increases from $37 \%$ to $49 \%$. At the deeper Site 967 , average percentages of kaolinite decrease from $30.5 \%$ (early Pliocene) to $18.4 \%$ (Quaternary), whereas smectite increases from $46 \%$ to $51 \%$. Only palygorskite behaves in a different way at both sites: its mean abundance decreases from $13.2 \%$ (early Pliocene) to $7.4 \%$ (Quaternary) at the shallowest Site 966, and increases from $7.3 \%$ to $11.9 \%$ at the deeper Site 967.

In each area, similar clay-mineral associations are present in the sapropels and adjacent oxidized sediments. However, significant variations in the average abundances of some clay minerals in the sapropels and adjacent sediments are observed, and the minerals involved differ with the position of the sites in the Eastern Mediterranean (Fig. 10). In the Ionian Basin (Site 964), sapropels are enriched in chlorite and random mixed-layer clays, depleted in kaolinite and palygorskite, and illite and smectite are constant. On the Mediterranean Ridge (Site 969), the content of random mixed-layer clays, palygorskite, and sepiolite increases in the sapropels, whereas smectite and kaolinite decrease, and chlorite and illite are constant. A similar trend is observed on the Eratosthenes Seamount (Sites 966, and 967): abundances of random mixed-layer clays and palygorskite increase, percentages of kaolinite decrease, and the other clay minerals do not show any significant variation.

The detailed mineralogy (percentages of clays, clay indices smectite/illite, kaolinite/illite, kaolinite/smectite) of the sapropels and surrounding sediments illustrates the evolution of the clay-mineral associations in relation to the development of the sapropels (Fig. 11). In the Ionian Basin (Site 964), the clay indices indicate that smectite increases relative to both illite and kaolinite, and illite increases relative to kaolinite in the sapropel. Comparison with the percentage of organic carbon clearly shows the association of the mineralogical change with the sapropel and that it persisted for some time after ter- 


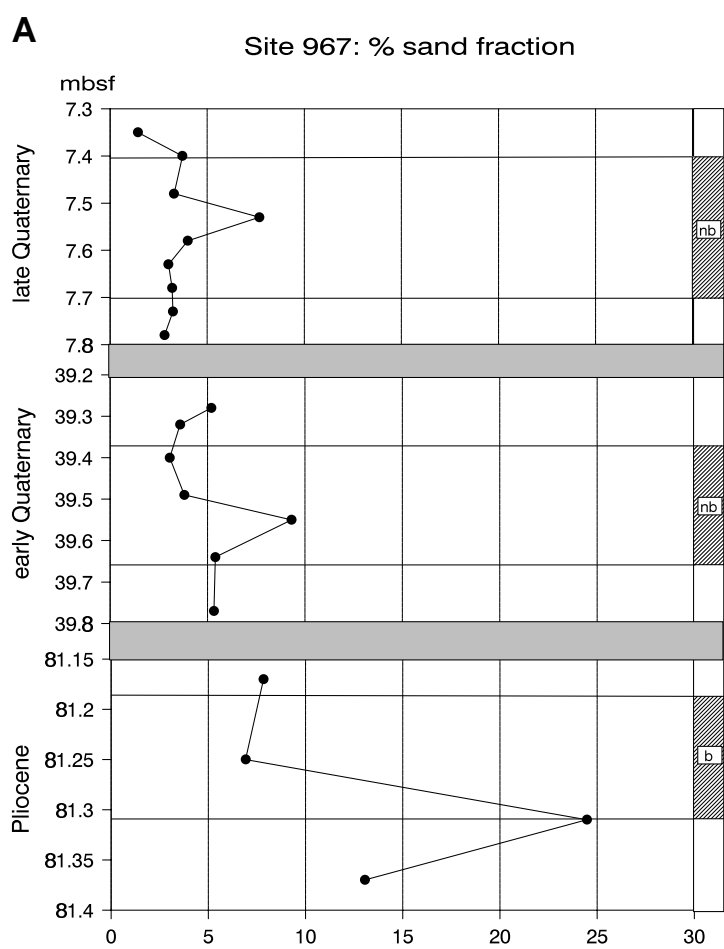

C

Site 967: \% pteropods and \% fish debris

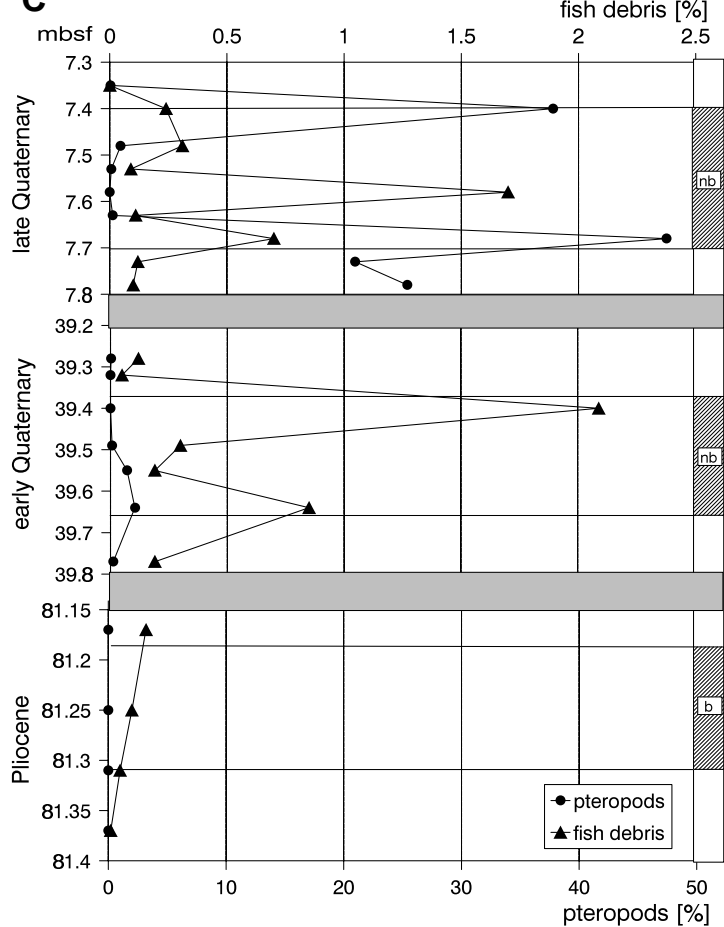

B Site 967: \% benthic and \% planktic foraminifers

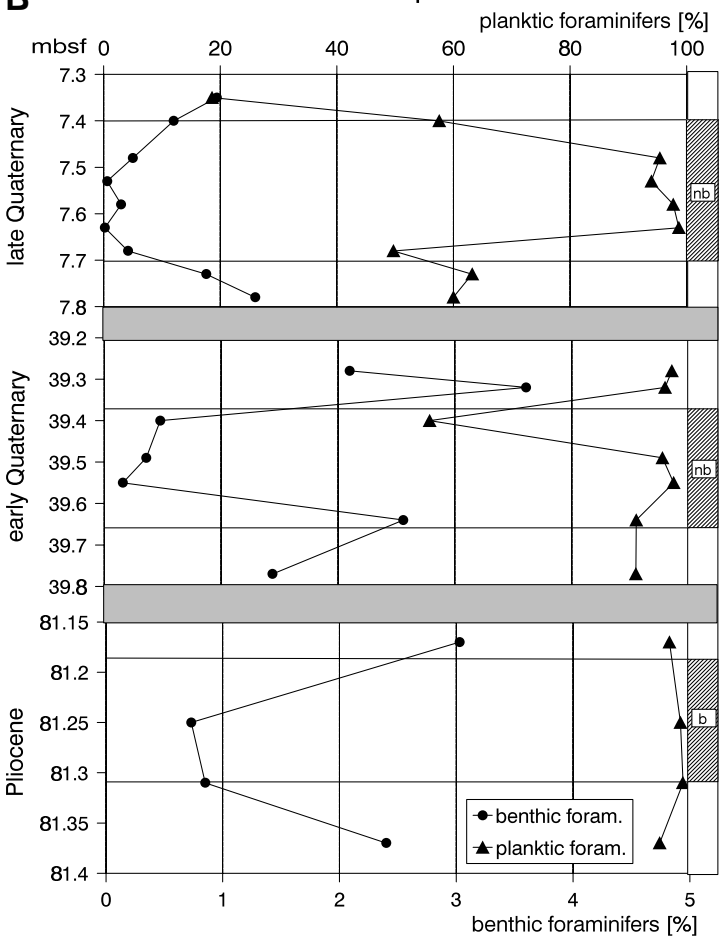

D
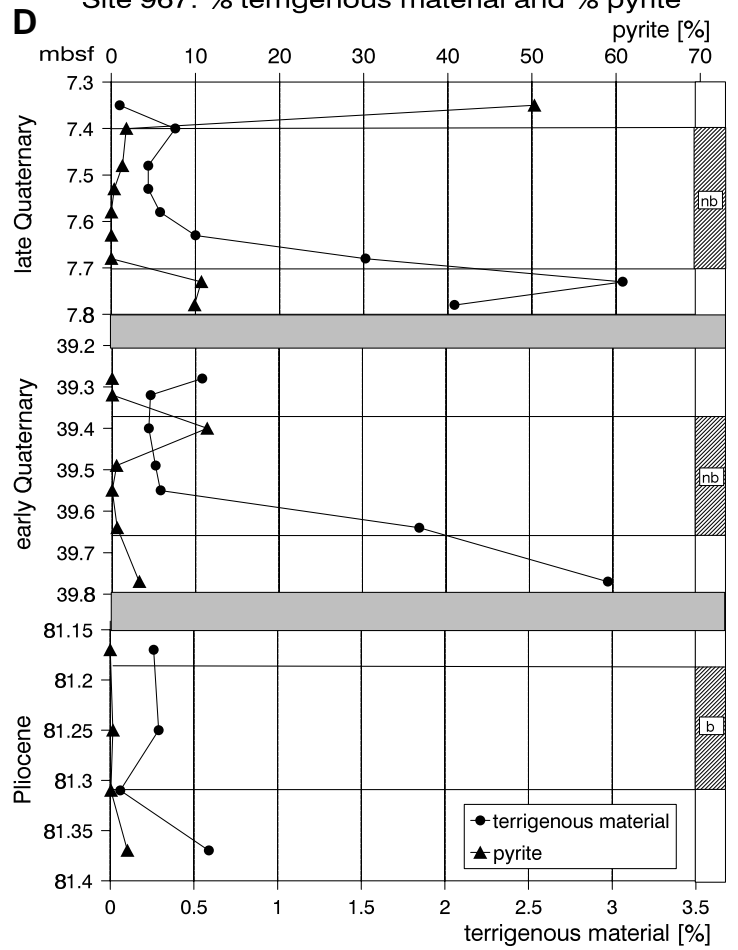

Figure 5. Results of coarse-fraction analysis of sediments from Site 967. Gray signature on right side $=$ sapropel; nb $=$ nonbioturbated; $b=$ bioturbated $($ information from core photographs in Emeis, Robertson, Richter, et al., 1966). A. Percent sand fraction. B. Percent benthic and percent planktic foraminifers of sand fraction. C. Percent pteropods and percent fish debris of sand fraction. D. Percent terrigenous matter and percent pyrite of sand fraction. (Continued on next page.) 
E

Site 967: Accumulation rate of benthic and planktic foraminifers

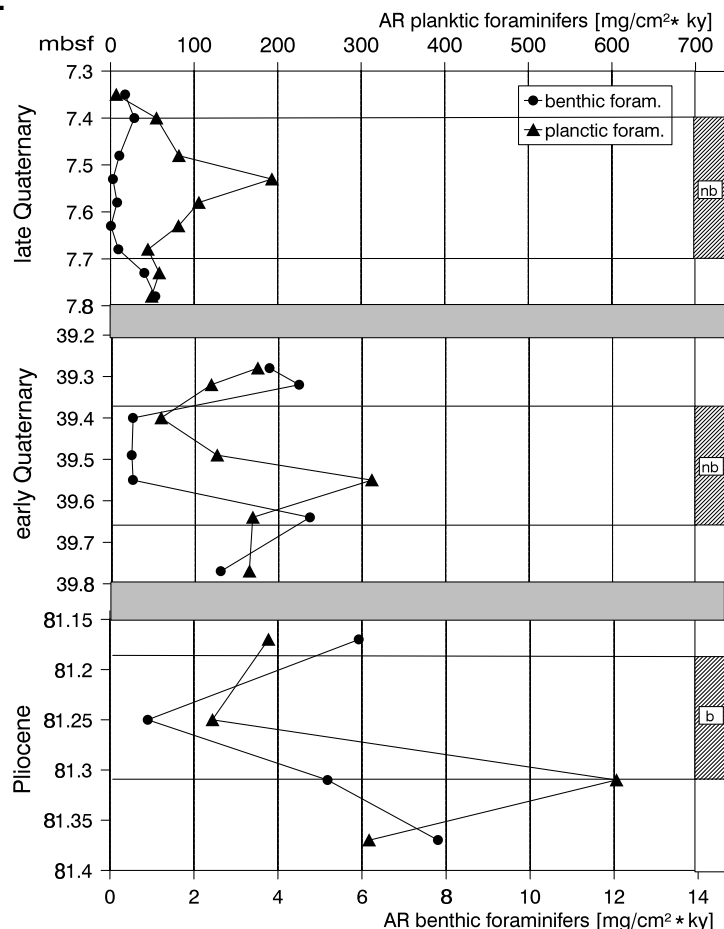

G

Site 967: Accumulation rate terrigenous material

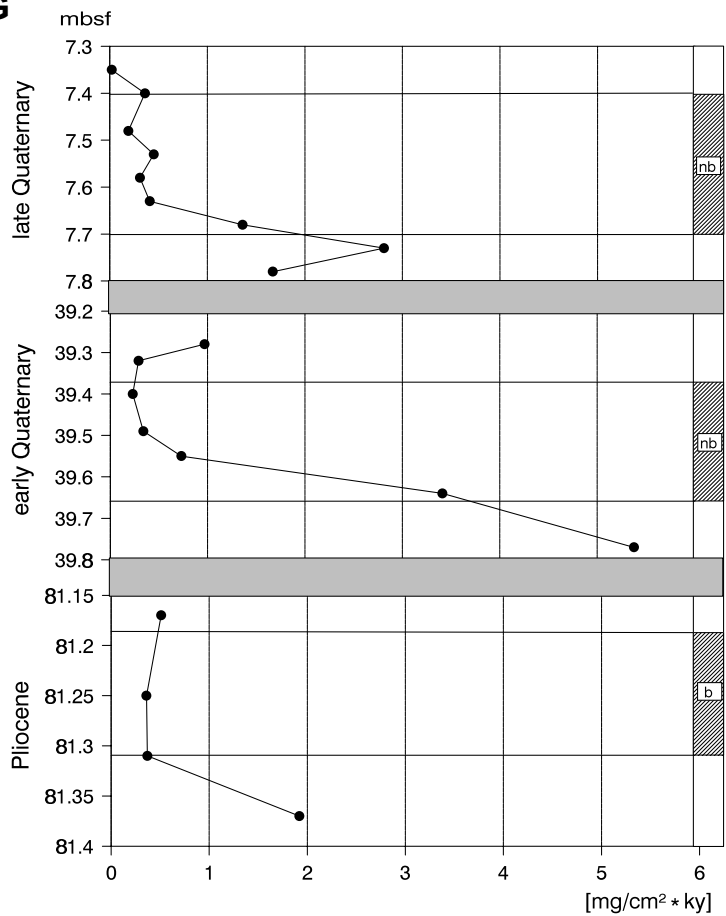

F Site 967: Accumulation rate of echinoids, ostracods and molluscs

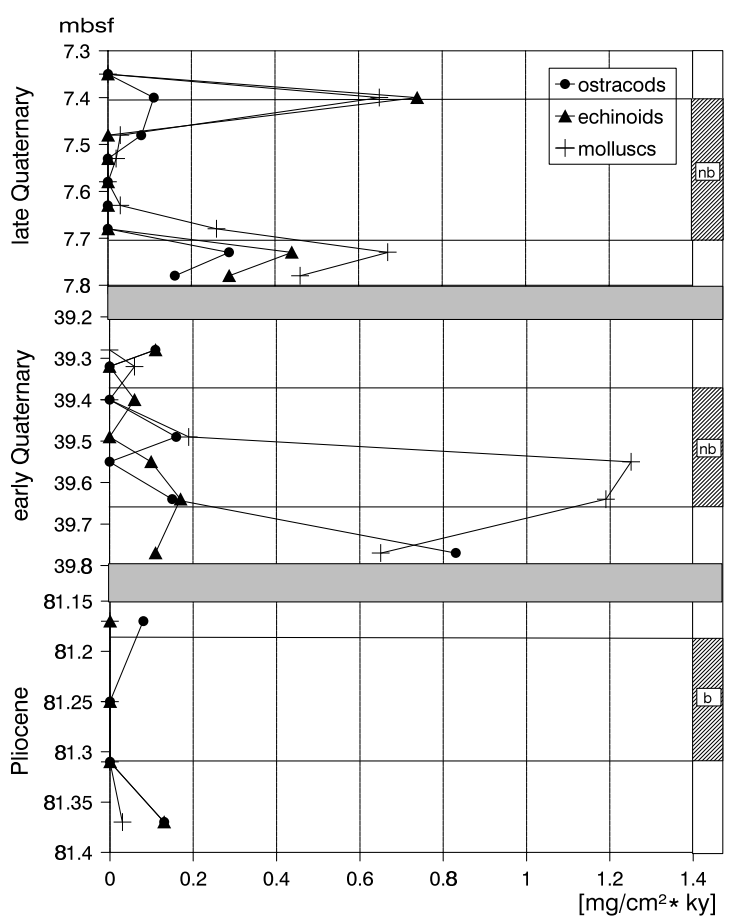

Site 967: Carbonate dissolution
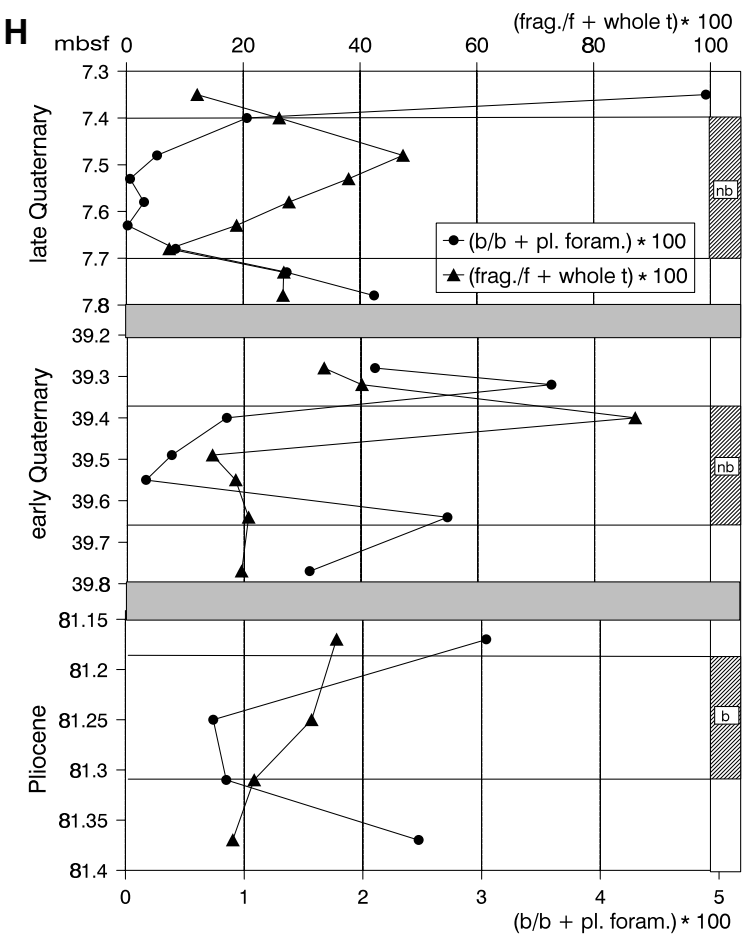

Figure 5 (continued). E. Accumulation rate of benthic and planktic foraminifers. F. Accumulation rate of echinoids, ostracods, and molluscs. G. Accumulation rate of sand-sized, terrigenous material. H. Carbonate dissolution, shown by means of benthic/planktic foraminifer ratios and fragmentation of planktic foraminifers (see text for details). (Continued on next page.) 


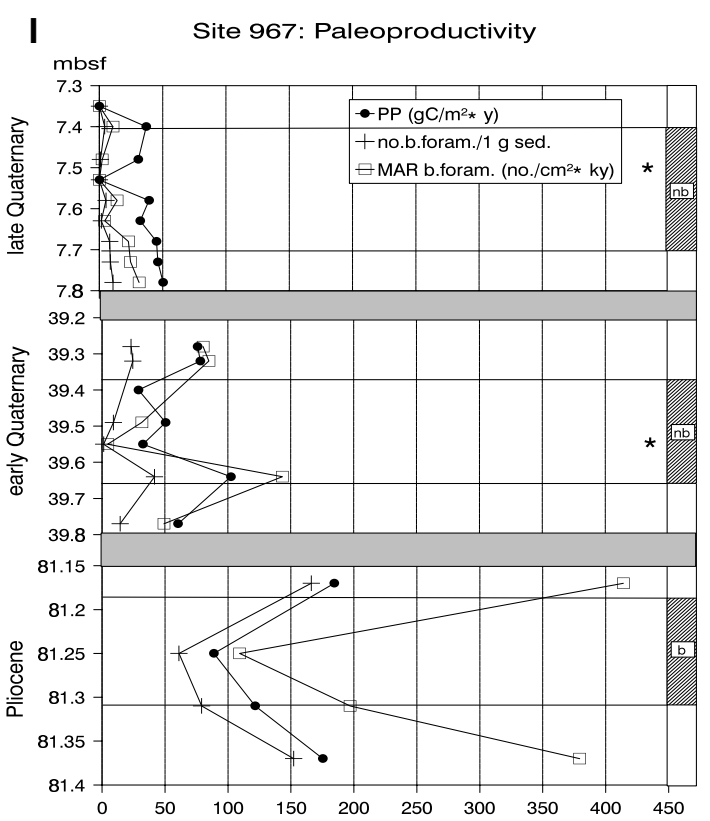

Figure 5 (continued). I. Paleoproductivity (PP), calculated after the formula of Herguera and Berger (1991) from benthic foraminifer numbers in $1 \mathrm{~g}$ of sediment (no.b.foram./1 g sed.) and their mass accumulation rates (MAR; b.foram. $\left[\mathrm{no} . / \mathrm{cm}^{2} \cdot \mathrm{k}\right.$.y.]). Star $=$ occurrence of radiolaria.

mination of the sapropel. Electron microscope observations indicate that the preservation of particles is poorer in the sapropels, where increased abundances of fleecy particles could reflect increased relative abundance of smectite. On the Mediterranean Ridge (Site 969), increased percentages of fibrous clays (palygorskite + sepiolite) are closely related to higher content of organic carbon. Also, increased illite relative to both smectite and kaolinite, and increased kaolinite relative to smectite, are associated with the maximum value of organic carbon. Most particles in the sapropels display subrounded contours. Fibers of palygorskite and sepiolite are shorter in the sapropel than in the adjacent oxidized sediments. Clusters of fibers are also observed in the sapropels. On the Eratosthenes Seamount, increased contents of illite relative to both smectite and kaolinite, and of smectite relative to kaolinite, are closely associated with increased organic carbon: maximum deviation of the clay indices and maximum content of organic carbon generally coincide. Short fibers of palygorskite and sepiolite are poorly preserved in the sapropels, where fleecy particles of smectite are also present. A better preservation of the particles is observed in the oxidized sediments, where neat, sharp boundaries of particles are frequent.

\section{DISCUSSION}

The results presented help to better understand the processes that might lead to sapropel deposition, including information on paleoproductivity before and after sapropel deposition; terrestrial input, which might act as a fertilizer; grain size; and origin of terrestrial material. These parameters also provide information on changes in transport paths and transport energy of continental clastic material, carbonate dissolution, and postdepositional changes in sapropels.

\section{Terrigenous Input}

\section{Origin and Significance of Terrigenous Particles}

The homogeneity of the clay-mineral associations throughout the Eastern Mediterranean during the entire Pliocene and Quaternary is remarkable (Table 3) and reflects the perenniality of the sources of particles. This association includes seven clay minerals, suggesting a variety of sources and transport processes to the areas of sedimentation.

1. Chlorite and illite are derived from the erosion of parent rock and poorly weathered substrates, such as cold and/or desert areas, and uplifted areas with active mechanical erosion (Chamley, 1989; Weaver, 1989). In the Eastern Mediterranean, chlorite and illite can originate from the northern side where uplifted areas are common in Italy, Greece, and Turkey, as well as from the southern side where desert areas are widespread. They are ubiquitous in the Eastern Mediterranean basins, but they are more abundant close to the northern margin where they represent $40 \%-80 \%$ of the clay fraction for the late Quaternary-age sediments (Chamley, 1971; Venkatarathnam and Ryan, 1971).

2. Random mixed-layer clays form when precipitation allows only a weak development of chemical weathering (Millot, 1970; Chamley, 1989). In the Eastern Mediterranean, random mixed-layer clays are more frequent near the northern margin where heavy precipitation occurs in the winter (Chamley, 1971; Cita et al., 1977).

3. Smectite develops in warm, poorly drained continental areas where precipitation and water spreading are followed by evaporation and concentration (i.e. monsoonal climates [Millot, 1970; Chamley, 1989]). In modern Mediterranean areas, steep relief on the northern margins and absence of precipitation on the southern margins prevent significant development of smectite in the soils, except in some areas of the Middle East and Asia Minor. The mineral is partially derived from erosion of sedimentary sequences that outcrop in Southern Europe and Northern Africa, but its major source is the Nile River (Chamley, 1971; Venkatarathnam and Ryan, 1971; Weaver, 1989), which flows through large, semi-arid areas of low relief in the upper and middle parts of its drainage basin: highest percentages of smectite in modern Mediterranean sediments are observed on the Nile cone.

4. Kaolinite originates from warm continental areas, where steep relief or high rainfall ensure an intense leaching of substrates and evacuation of the solutions by runoff (Millot, 1970; Chamley,1989). These conditions are present only locally in Southern Europe and in the upper drainage basin of the Nile. In addition, some kaolinite is eroded from sedimentary sequences that outcrop in desert areas of North Africa and transported by winds to the sea (Venkatarathnam and Ryan, 1971; Weaver, 1989).

5. Formation of palygorskite and sepiolite has not been described in modern continental environments; however, palygorskite has been found in calcareous pedogenic crusts of subarid Quaternary Saharan environments (Millot et al., 1977). Palygorskite and sepiolite have been mostly described in Paleogene peri-marine and shallow-marine environments where chemical elements ( $\mathrm{Mg}, \mathrm{Si}$, and others) supplied by running continental waters are concentrated by intense evaporation (Millot, 1970; Weaver, 1989). Sediments containing abundant palygorskite and sepiolite widely formed in the Paleogene Tethys environments and now principally outcrop in desert areas of North Africa (Millot, 1970; Chamley, 1971). The last episode of widespread formation of palygorskite and sepiolite in Mediterranean areas occurred during the Messinian Salinity Crisis (Chamley, 1989). Low amounts of detrital palygorskite and sepiolite are known in most upper Quaternary deposits of the Eastern Mediterranean, but higher contents (up to 25\%) occur off desert areas of Libya (Chamley, 1971).

Variations of the relative proportion of the clay species according to the position of the sites (Table 3 ) illustrate the relative contribution 
A

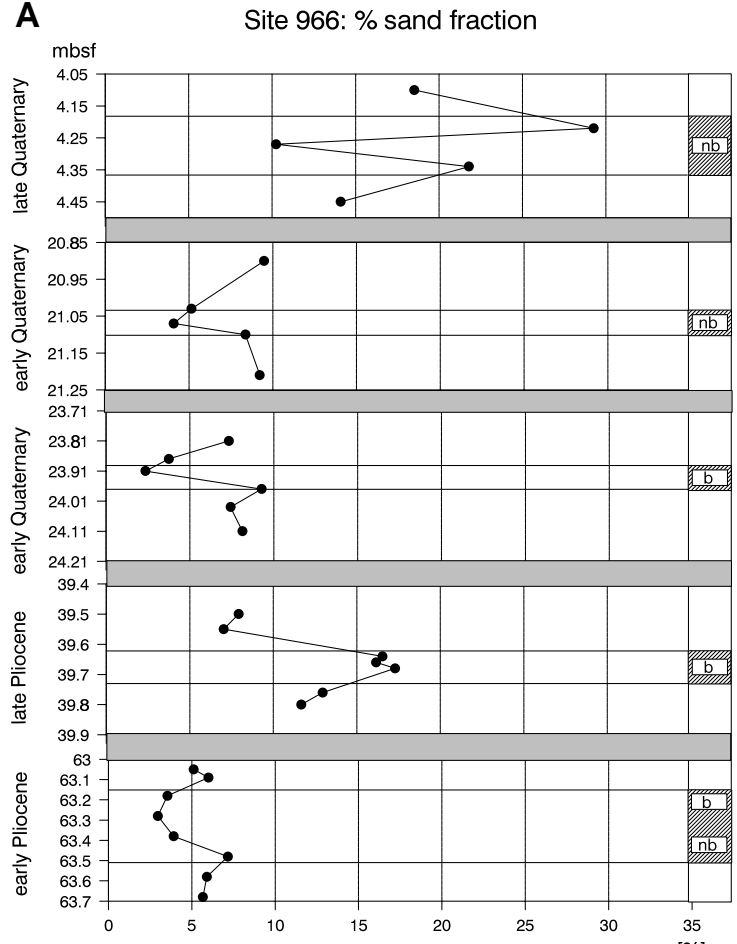

[\%]

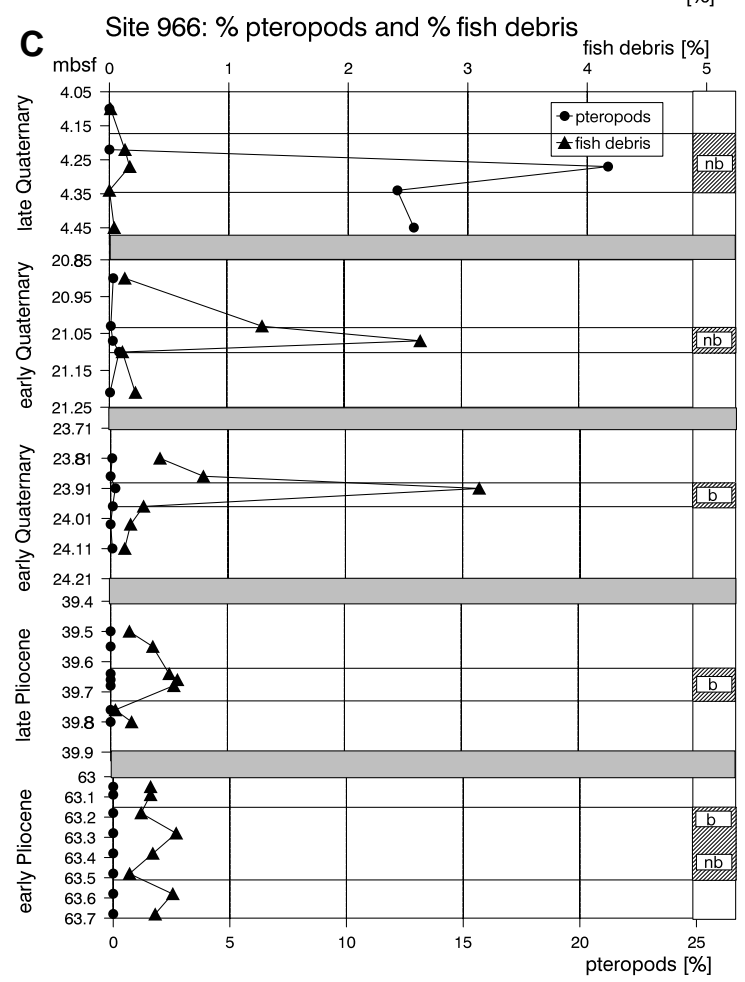

B Site 966 : \% benthic and \% planktic foraminifers

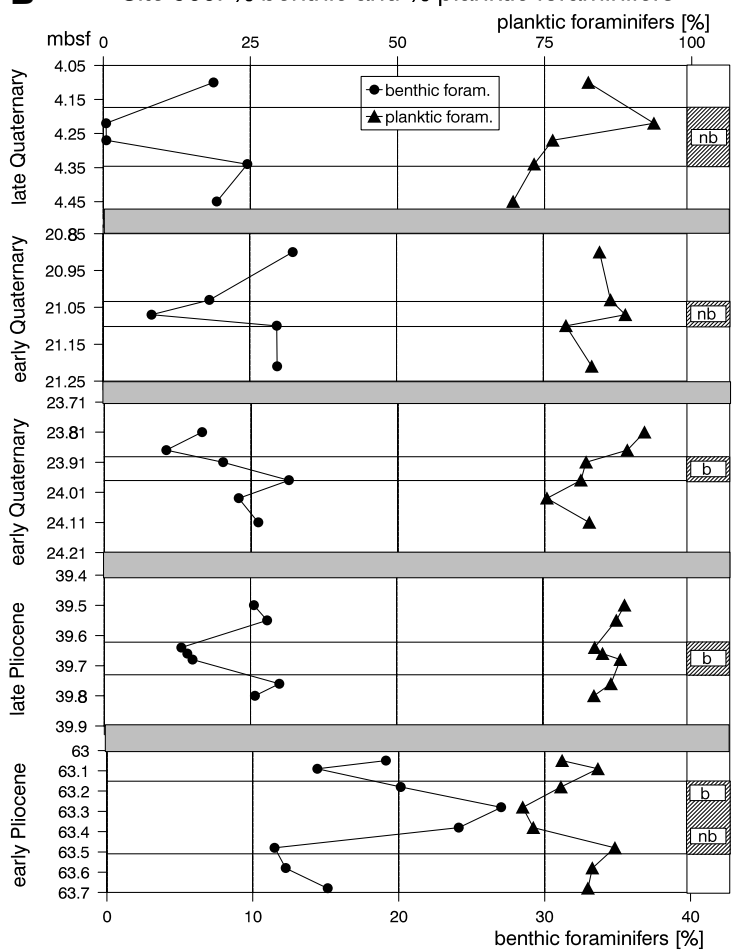

D Site 966: \% terrigenous material, \% pyrite and \% fecal pellets

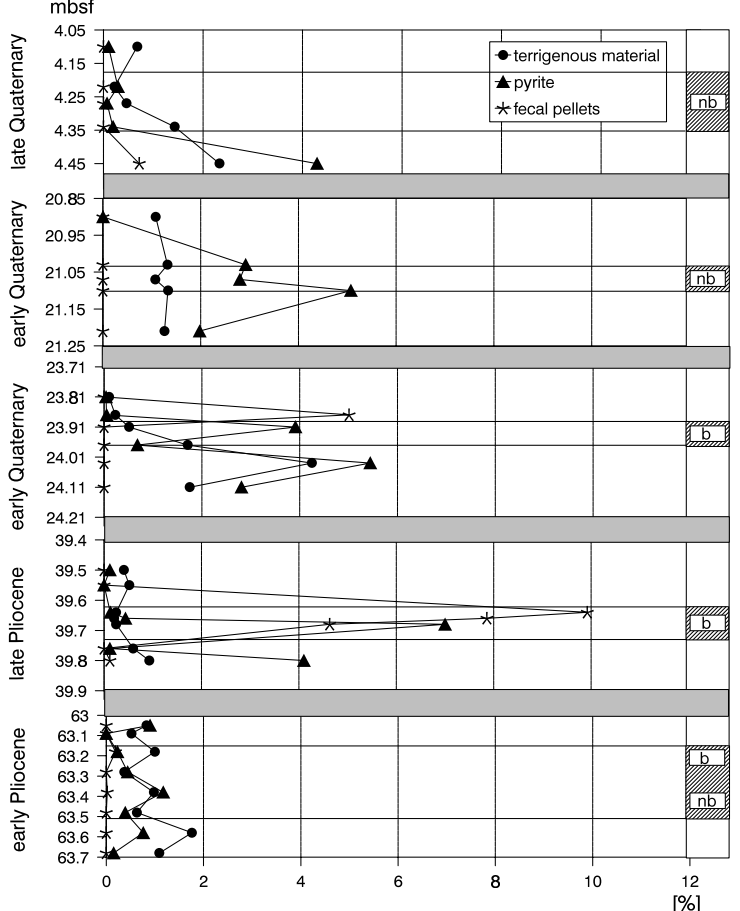

Figure 6. Results of coarse-fraction analysis of sediments from Site 964. Gray signature on right side = sapropel; nb = nonbioturbated; $b=$ bioturbated $($ information from core photographs in Emeis, Robertson, Richter, et al., 1966). A. Percent sand fraction. B. Percent benthic and percent planktic foraminifers of sand fraction. C. Percent pteropods and percent fish debris of sand fraction. D. Percent terrigenous matter, percent pyrite, and percent fecal pellets of sand fraction. (Continued on next page.) 
E Site 966: Accumulation rate of benthic and planktic foraminifers

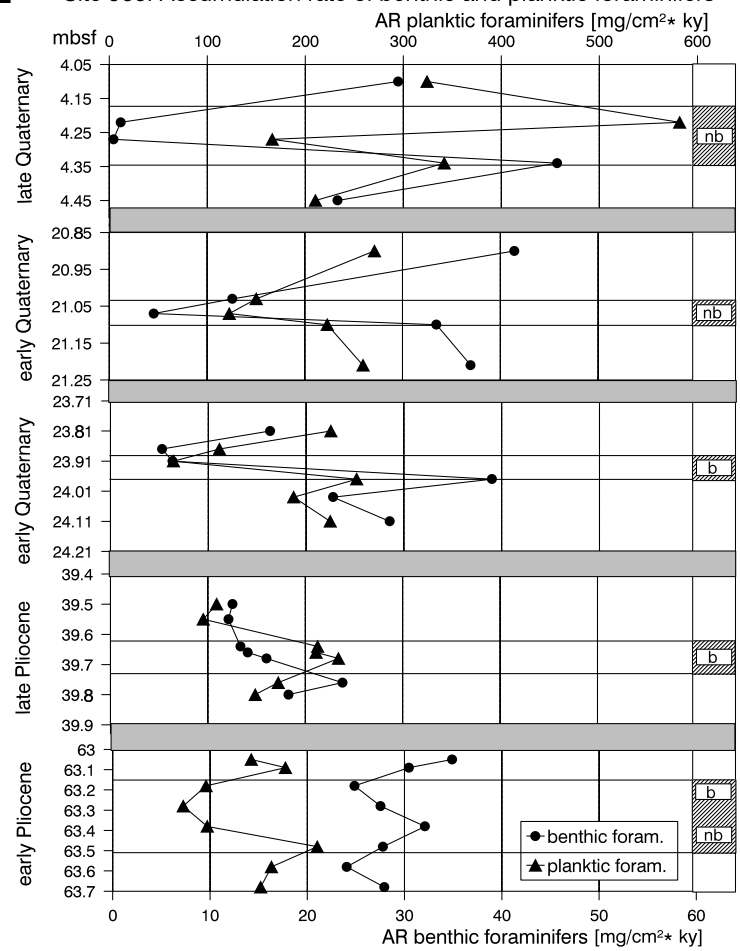

G

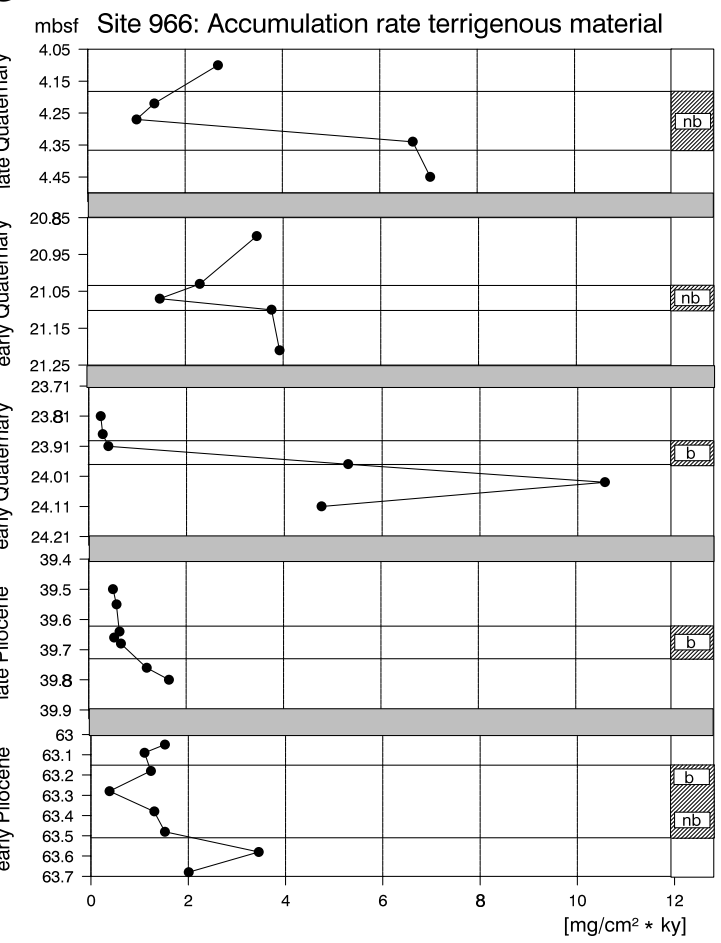

F Site 966: Accumulation rate of echinoids, ostracods and molluscs

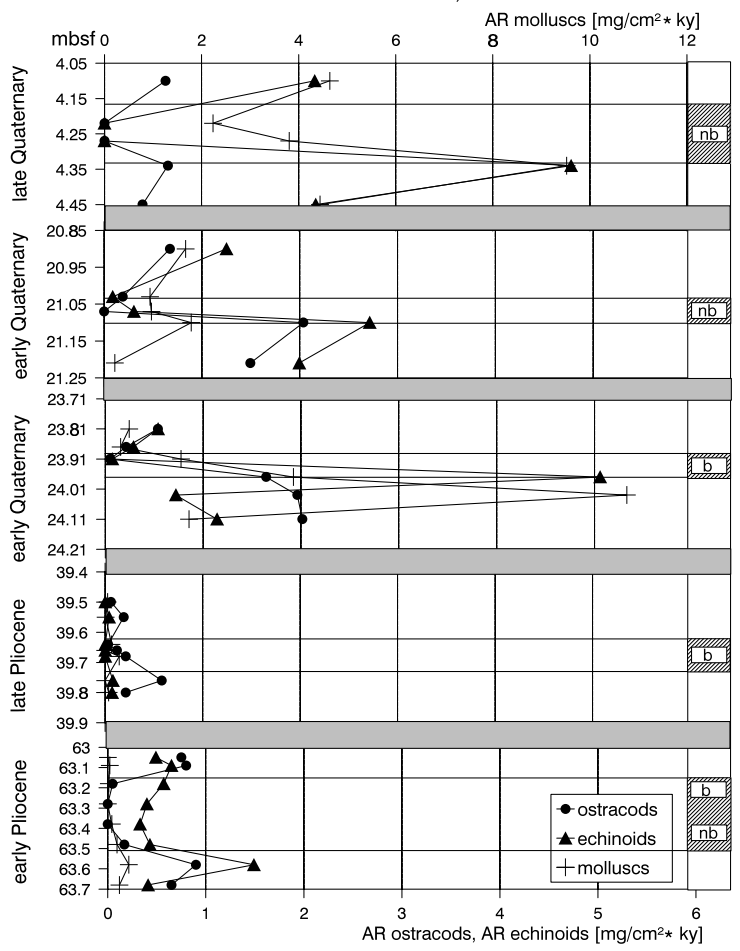

H
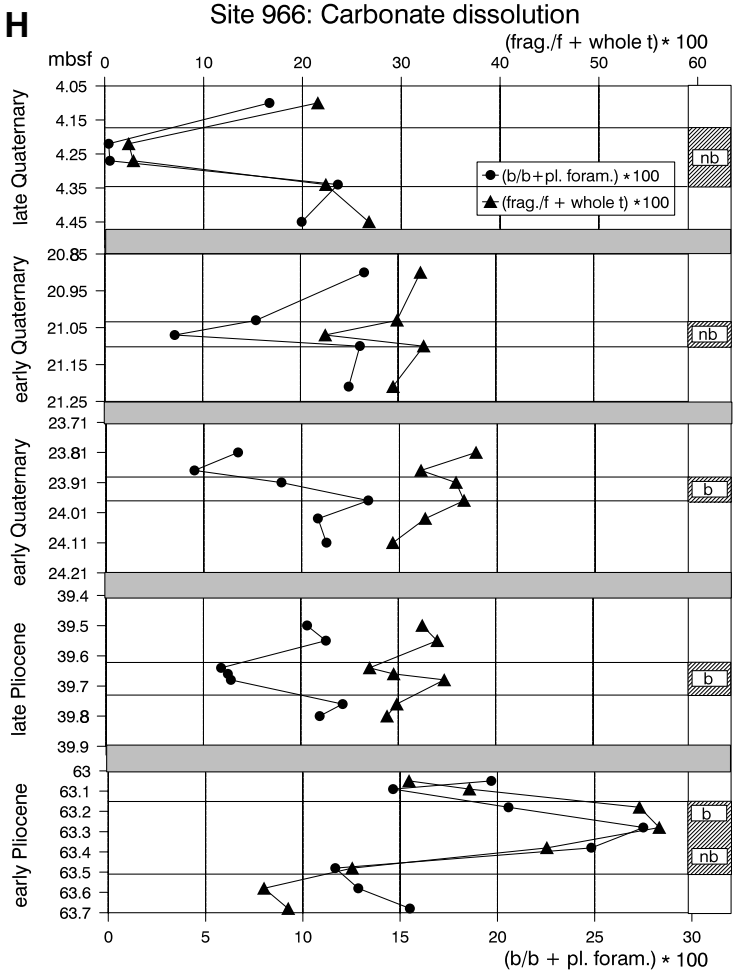

Figure 6 (continued). E. Accumulation rate of benthic and planktic foraminifers. F. Accumulation rate of echinoids, ostracods, and molluscs. G. Accumulation rate of sand-sized, terrigenous material. H. Carbonate dissolution, shown by means of benthic/planktic foraminifer ratios and fragmentation of planktic foraminifers (see text for details). (Continued on next page.) 


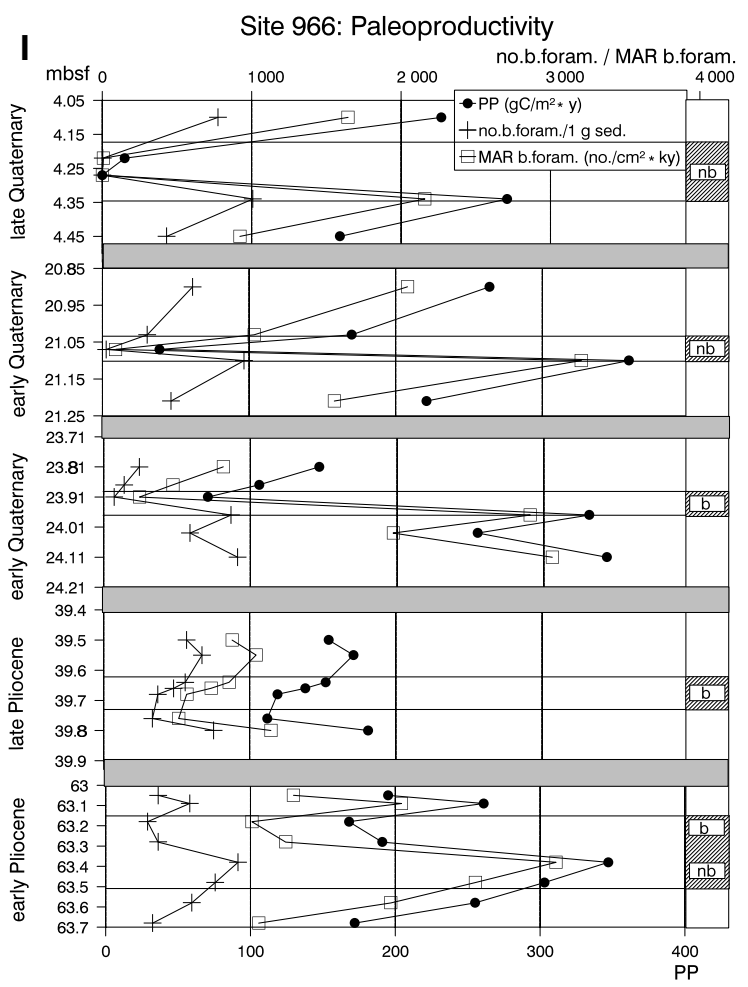

Figure 6 (continued). I. Paleoproductivity (PP), calculated after the formula of Herguera and Berger (1991) from benthic foraminifer numbers in $1 \mathrm{~g}$ of sediment (no.b.foram./1 g sed.) and their mass accumulation rates (MAR; b.foram. [no./ $\left.\left.\mathrm{cm}^{2} \cdot \mathrm{k} . \mathrm{y}.\right]\right)$.

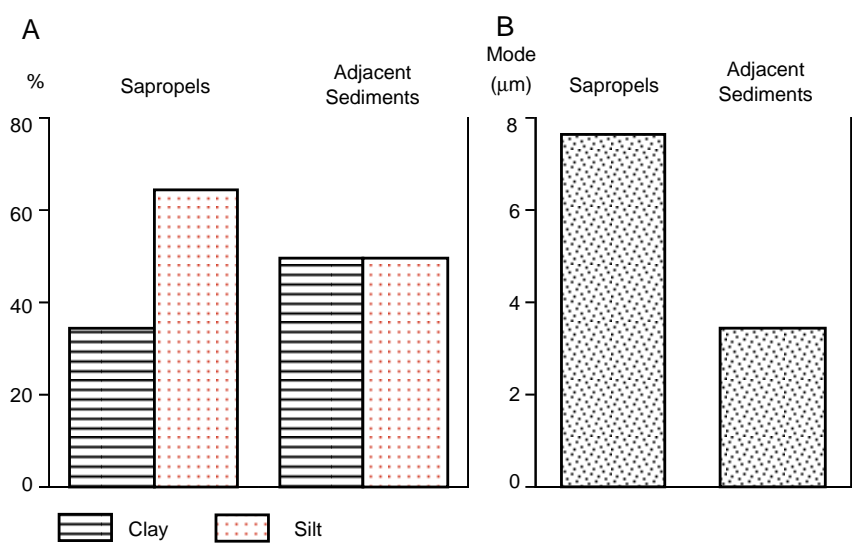

Figure 7. (A) Average abundance of silt and clay and (B) mode of grain-size distribution in sapropels and adjacent oxidized sediments at all sites. Note higher mode and percentage of silt in the sapropels.

of the different sources of particles to Eastern Mediterranean sediments during the Pliocene and Quaternary.

1. In the Ionian Basin (Site 964), dominance of chlorite, illite, and random mixed-layer clays (39\% of the clay fraction), together with some kaolinite, shows the importance of particles from Europe, mostly supplied by runoff and further transported by intermediate waters from the Adriatic (Chamley, 1971; Dominik and Stoffers, 1979; Malanotte-Rizzoli and Hecht, 1988). Palygorskite and sepiolite ( $8 \%$ of the clay fraction) are supplied from North Africa by winds, as shown by their pres-
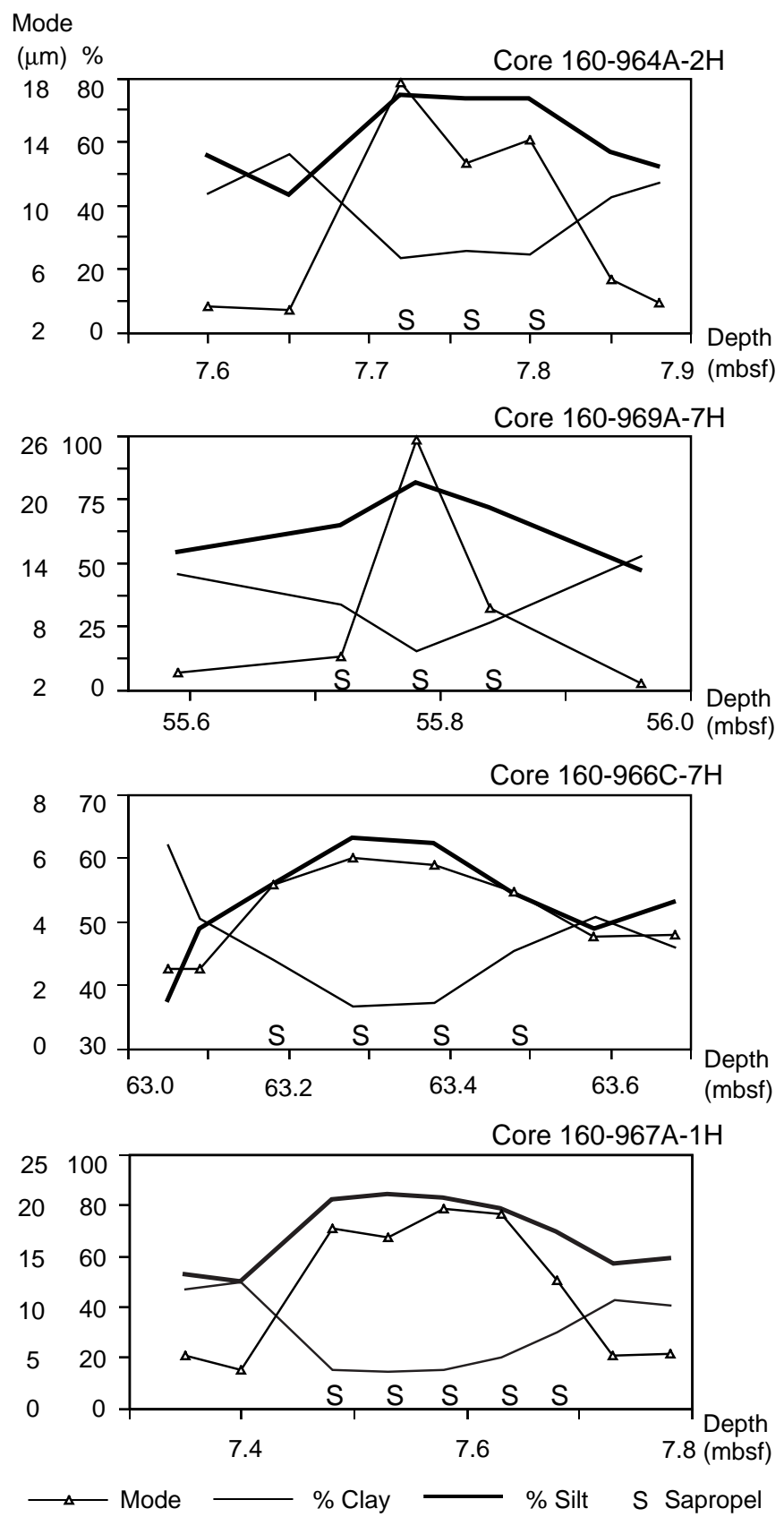

Figure 8. Detail of grain-size analysis in the Ionian Basin (Core 160-964A$2 \mathrm{H}$ ), on the Mediterranean Ridge (Core 160-969A-7H) and on the Eratosthenes Seamount (Cores 160-966C-7H and 160-967A-1H). Note higher mode of grain-size distribution in sapropels and negative correlation between percentage of clay and silt.

ence in eolian dusts, together with other clays including some smectite, kaolinite, and illite (Tomadin et al., 1984).

2. On the Mediterranean Ridge (ODP Site 969), chlorite, illite, and random mixed-layer clays still dominate the clay fraction (33\%), indicating important contribution of European sources of particles and runoff (including from Crete). Significant amounts of palygorskite and sepiolite $(18 \%$ of the clay fraction) show the importance of detrital supply from Africa by winds.

3. On the Eratosthenes Seamount (ODP Sites 966 and 967), dominance of smectite $(43 \%-48 \%)$ is a consequence of the dis- 
persal in the Mediterranean of the suspended load of the Nile. Surface and Levantine intermediate-water circulation ensure the distribution of the particles into the Levantine Basin (Malanotte-Rizzoli and Hecht, 1988; Weaver, 1989). Slightly lower percentages of smectite (and higher amounts of chlorite, illite, random mixed-layer clays, and kaolinite) at the shallowest Site 966 result probably from some dilution by particles eroded from uplifted areas from nearby Cyprus. Significant amounts of palygorskite and sepiolite at both sites suggest some supply by wind from arid areas of North Africa and the Middle East.

Although the clay-mineral association remains the same at all locations during the Pliocene and Quaternary, slight variations in the abundance of the different clay species suggest an evolution of the conditions of formation and distribution of the particles through time. At all sites, decreased contents of kaolinite are observed in the sediments from the early Pliocene to the Quaternary. This is associated with increased abundance of smectite. A similar evolution has been described in different areas of the world ocean, including the central Atlantic off West Africa (Robert and Chamley, 1987). Illite contents decrease in the Ionian Basin, where it is partly transported from Europe by deep waters from the Adriatic, but increase on the Mediterranean Ridge, where the mineral is partly derived from North Africa. On the Eratosthenes Seamount, palygorskite decreases at the shallowest site but increases at the deepest site. This evolution of the clay association through time suggests decreased humidity and stronger seasonality of precipitation and some reorganization of the pattern of circulation, which could be related to the development of the Arctic glaciation and associated cooling during the Pliocene.

\section{Terrigenous Particles and Development of Sapropels}

Comparison of the clay-mineral association in the sapropels and adjacent sediments (Figs. 9, 10) clearly shows the permanence of the main characteristics of sedimentation in the Eastern Mediterranean

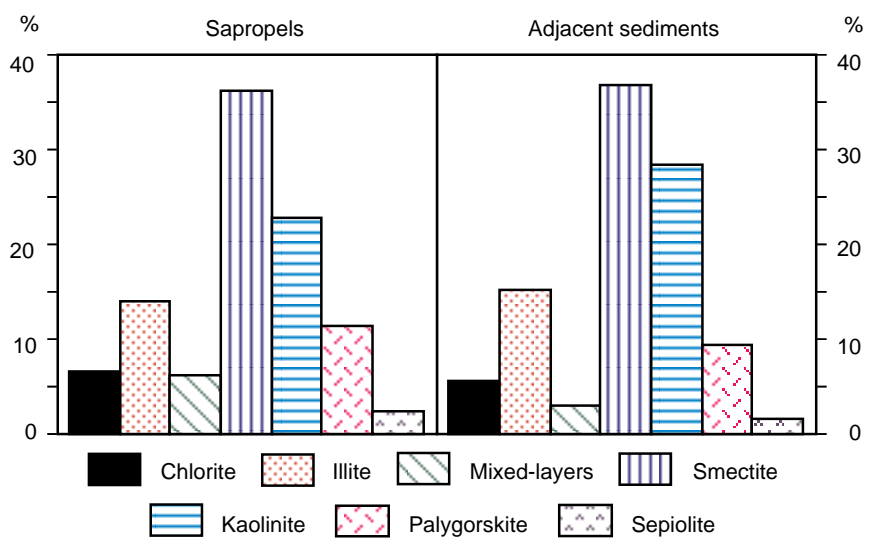

Figure 9. Average abundance of clay minerals in sapropels and adjacent oxidized sediments at all sites. Note similarity of clay associations and variations in percentages of individual clay minerals. during the Pliocene and Quaternary. No specific mineral characterizes the sapropels. The clay mineral that is the most sensitive to diagenetic alteration by organic acids is palygorskite (Sigl et al., 1978). However, palygorskite has been observed in all sedimentary sequences, where its abundance is sometimes higher in the sapropels than in adjacent sediments. Moreover, maximum abundance of palygorskite and sepiolite has been recorded in the sapropel that contains the maximum percentage of organic carbon (Figs. 2, 11). This observation suggests the absence of any significant diagenetic alteration in the sapropels investigated here. Preservation of clay particles is sometimes poorer in the sapropels than in adjacent sediments; however, this is combined with the presence of short fibers of palygorskite and sepiolite, sometimes associated in clusters, and with subrounded contours of some particles (Pl. 1,2). Therefore, poorer preservation of clay particles in some sapropels could result from weak alteration during early diagenesis or transport (Sigl et al., 1978). As a consequence, clay-mineral associations in the sapropels contain information on conditions of formation on the continent (climate, morphology) and of transport (circulation) to the area of sedimentation.

Comparison of the clay-mineral association in the sapropels and adjacent sediments (Figs. 9,10) also indicates that the sources of terrigenous particles remained the same during the Pliocene and Quaternary. However, variations in the abundance of the clay species are not identical at all sites (Fig. 10) or sometimes in all sapropels at any given site.

In the Ionian Basin (Site 964), chlorite and random mixed-layer clays increase in the sapropels, indicating increased erosion of poorly weathered substrates. Kaolinite is present in lower amounts than in the adjacent sediments, but is still abundant (23\%). Also, the abundance of palygorskite ( $9 \%$ on the average in oxidized sediments) decreases to less than $5 \%$ in the sapropels, indicating lower contribution of African sources. Detailed analyses (Fig. 11) show a slight increase of smectite (from smectite/illite and kaolinite/smectite ratios), and suggest increased erosion of sedimentary sequences that outcrop in Southern Europe. It is likely that intensified erosion of European uplifted areas has been associated with sapropel deposition, with the particles being transported principally by runoff and then by Adriatic waters to the deep Ionian Basin. A similar observation has been made for Sapropel S1 in the Aegean Sea, where accumulation of terrigenous particles results from erosion processes during disintegration of continental ice sheets and transport by meltwater flow (Aksu et al., 1995). In the deep Ionian Basin, the same evolution of the clay association has been observed in all sapropels, including a sapropel of mid-Pliocene age that was deposited before full development of the Arctic cryosphere. Therefore, we suggest that increased runoff in European areas close to the Adriatic and Ionian Basin resulted from intensified precipitation, at least during Pliocene deposition of sapropels.

On the average, sapropels from the Mediterranean Ridge (ODP Site 969) are characterized by increased contents of palygorskite and sepiolite (Fig. 10). The detailed study (Fig. 11) clearly shows that maximum abundance of these minerals occurred when the sapropel environment reached full development. This observation indicates that increased erosion of sediments in North Africa (especially Libya) and transport of particles by winds have been associated with the sapropels of the Mediterranean Ridge. Concomitant, slight increases

Table 3. Percentages of the main clay minerals at the four investigated sites.

\begin{tabular}{cccccccc}
\hline Site & $\begin{array}{c}\text { Chlorite } \\
(\%)\end{array}$ & $\begin{array}{c}\text { Illite } \\
(\%)\end{array}$ & $\begin{array}{c}\text { Mixed-layer } \\
\text { clays } \\
(\%)\end{array}$ & $\begin{array}{c}\text { Smectite } \\
(\%)\end{array}$ & $\begin{array}{c}\text { Kaolinite } \\
(\%)\end{array}$ & $\begin{array}{c}\text { Palygorskite } \\
(\%)\end{array}$ & $\begin{array}{c}\text { Sepiolite } \\
(\%)\end{array}$ \\
\hline 964A & 9 & 22 & 8 & 24 & 29 & 7 & 1 \\
969A & 10 & 20 & 3 & 29 & 20 & 15 & 3 \\
966A and 966C & 4 & 9 & 4 & 43 & 28 & 10 & 2 \\
967A & 4 & 8 & 4 & 48 & 23 & 10 & 3 \\
\hline
\end{tabular}




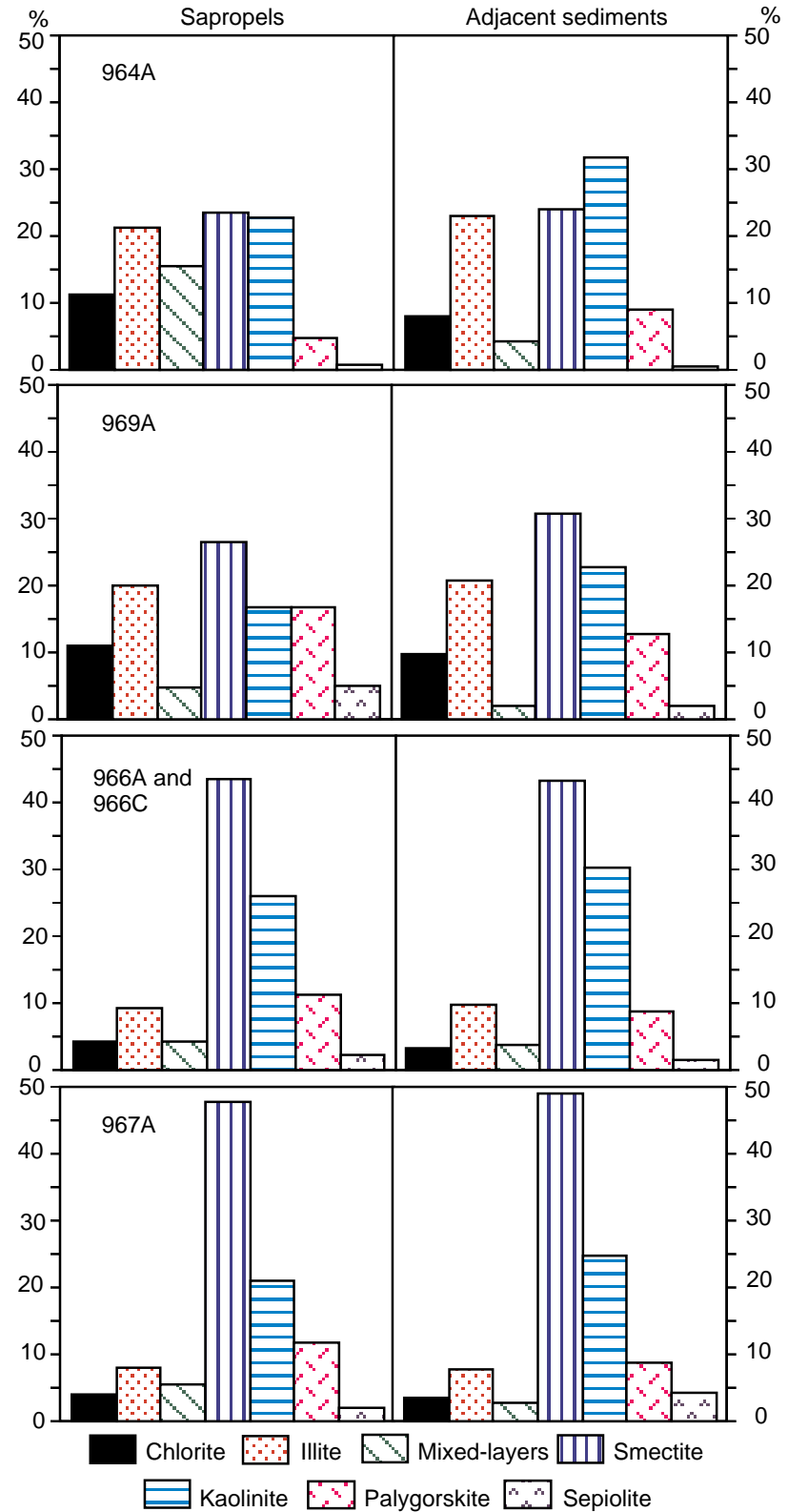

Figure 10. Average abundance of clay minerals in sapropels and adjacent oxidized sediments, for the Ionian Basin (Hole 964A), Mediterranean Ridge (Hole 969A), shallow-water depth of the Eratosthenes Seamount (Holes 966 A and 966C), and intermediate-water depth of the Eratosthenes Seamount (Hole 967A). Note similarity of clay association at all locations, variations in relative abundance of individual clay minerals according to the location, and specific changes of the percentages of individual clay minerals in sapropels for each location.

of the percentages of chlorite and random mixed-layer clays (Fig. 10), and decreases of smectite/illite and kaolinite/illite indices (Fig. 11), suggest increased erosion of poorly weathered substrates. Most particles probably come from Southern Europe, and especially from Crete (located $\sim 100 \mathrm{~km}$ north of the site) by runoff. All the sapropels at this site do not share the same pattern of evolution of the clay mineral association. In a sapropel of early Pliocene age (Core 160-969A$10 \mathrm{H}$ ) increased percentages of palygorskite and sepiolite are associated with slight increases of smectite and kaolinite (instead of chlorite, illite, and random mixed-layer clays). Because the early Pliocene was a warm interval (Crowley and North, 1991), additional moisture
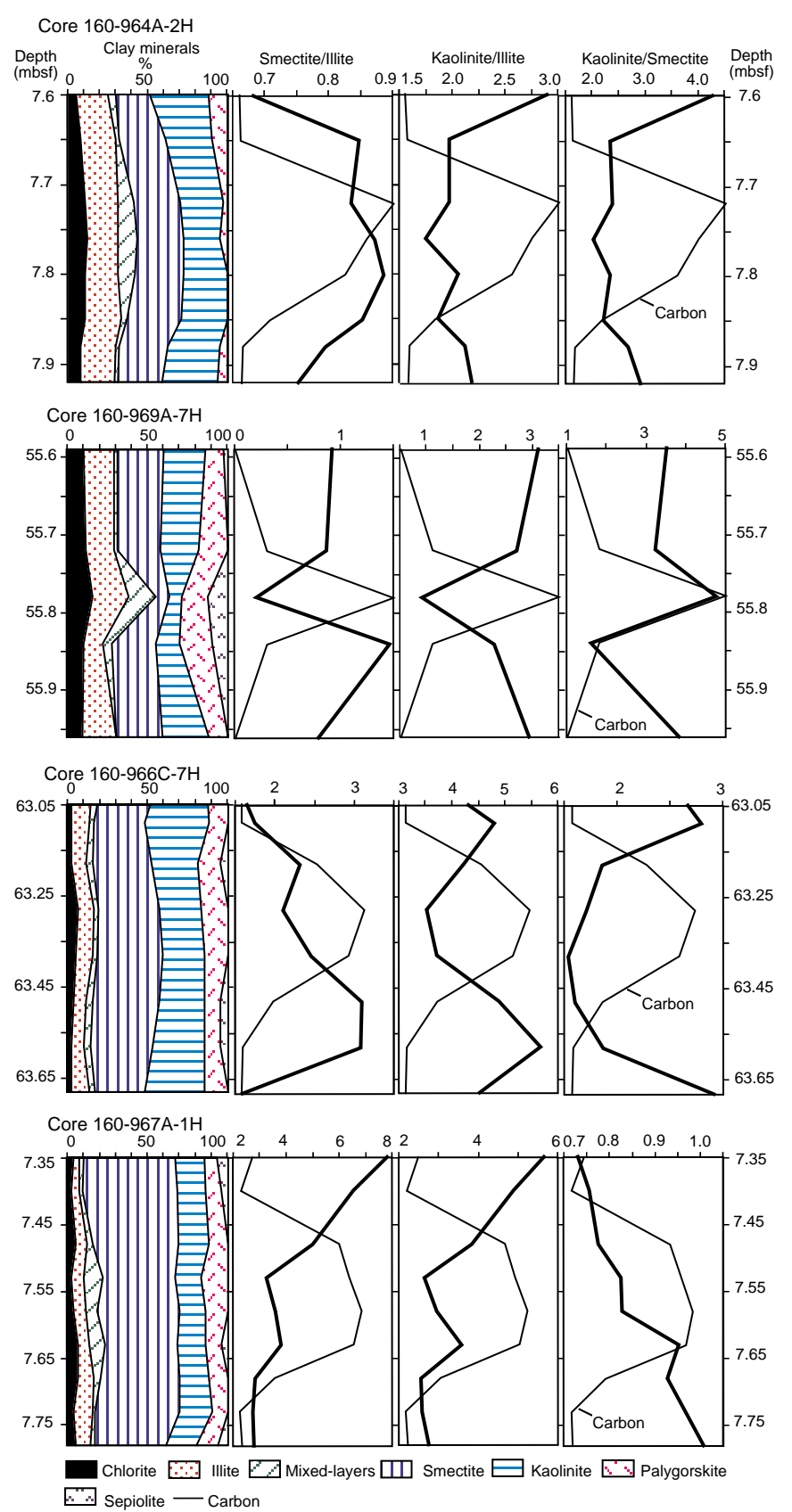

Figure 11. Detail of clay-mineral analysis in the Ionian Basin (Core 160964A-2H), on the Mediterranean Ridge (Core 160-969A-7H), and on the Eratosthenes Seamount (Cores 160-966C-7H and 160-967A-1H). Note similarity of clay association in sapropels and adjacent oxidized sediments, and detailed variations of the percentages of clay minerals and clay mineral ratios with the content of organic carbon.

may have led to increased chemical weathering in the source areas of the particles.

On the Eratosthenes Seamount (Sites 966 and 967), the average evolution of the clay-mineral association in the sapropels relative to the adjacent sediments is roughly similar at both sites. Slightly increased contents of chlorite and random mixed-layer clays in the sapropels at both sites (Fig. 10) suggest enhanced erosion of poorly weathered substrates, most probably in nearby Cyprus. Also, increases of palygorskite in the sapropels suggest intensified erosion in North Africa and the Middle East and transport of particles by winds to the area of sedimentation. However, detailed study of the sapropels 
illustrates the variability of the sedimentation on the Eratosthenes Seamount (Fig. 11).

1. At the Site 966, Quaternary and late Pliocene sapropels also show slight increases in kaolinite, illite, or smectite, as seen from the clay-mineral ratios. Increased smectite is associated with higher content of palygorskite. This suggests that distal terrigenous supply from the Nile and eolian particles have been diluted by dominant input of particles of proximal origin (Cyprus) by runoff during deposition of some sapropels. Early Pliocene sapropels show increased contents of smectite, an observation that indicates that during this warm interval deposition of sapropels was associated with intensified chemical weathering in the source areas and with enhanced contribution of the Nile to the sedimentation of the Eastern Mediterranean.

2. At Site 967 , all the sequences investigated show an increasing trend of smectite relative to both illite and kaolinite, evidenced from the clay-mineral ratios. The trend starts with the sapropel and persists in the oxidized, overlying sediment (Fig. 11). We hypothesize that this trend could indicate a continuously increasing contribution of the detrital supply of the Nile at 2500 $\mathrm{m}$ water depth. It could be the consequence of an evolving production and circulation of Levantine intermediate water, a characteristic of the modern Mediterranean, produced especially in winter by the sinking of cold surface waters in the easternmost Mediterranean (Malanotte-Rizzoli and Hecht, 1988).

The major pattern of the grain-size distribution of the fine terrigenous fraction $(<63 \mu \mathrm{m})$ is a significant increase of the silt fraction (4-63 $\mu \mathrm{m}$ ) in the sapropels (Fig. 7). Absence of relation to occurrences of pyrite suggests that authigenesis did not play a role in the variations of grain size in the sapropels and adjacent sediments. The sapropels may have developed in a higher energy environment than the adjacent sediments. Larger grain size of the terrigenous fraction of the sediment has already been correlated to strengthened circulation in the North Atlantic (McCave et al., 1995; Fagel et al., 1997). In the Eastern Mediterranean, increased terrigenous supply by precipitation and runoff from proximal (Southern Europe, Crete, and Cyprus) and distal (Nile) sources has probably been associated with intensified marine and/or atmospheric circulation; this allowed transport and deposition of coarser particles to the sites. We have no indication that the grain size of the terrigenous particles evolved significantly before the beginning of the sapropels. These findings are corroborated by the variations of the mode of the grain-size distribution (Fig. 7), which is higher in the sapropels $(7.6 \mu \mathrm{m})$ than in the adjacent sediments $(3.4 \mu \mathrm{m})$. As the sources of particles remained the same during the Pliocene and the Quaternary, variations in the intensity of marine and atmospheric circulation could be responsible for most of the mineralogical variations observed in the sapropels.

\section{Paleoproductivity and its Relation to Terrigenous Input}

Increase in export productivity during periods of sapropel deposition has been assumed as one possible factor leading to increased organic carbon content of sapropels (see discussion in Rohling, 1994). Here we try to reconstruct export productivity in the oxygenated sediments surrounding sapropels by means of the accumulation rates of benthic foraminifers, assuming that they depend on food supply from production in surface waters (Herguera and Berger, 1991). The aim is to investigate whether productivity was different in periods shortly before sapropel deposition than afterwards. This method does not give hints as to productivity during sapropel deposition, because anoxia prevented benthic life. Bioturbated sapropels contain some benthic foraminifers, but they do not give any hint as to productivity.
Late Quaternary oxygenated sediments yield results that are similar to those from oceanographic investigations in the Eastern Mediterranean Sea (Bethoux, 1989): $25-50 \mathrm{gC} / \mathrm{m}^{2} \cdot \mathrm{yr}$. Thus they prove the validity of the method of Herguera and Berger (1991) for those areas where lateral transport of benthic foraminifers is minor or absent. The surprisingly high values on the Eratosthenes Seamount are difficult to understand, because the present-day oceanography shows downwelling (Emeis, pers. comm., 1996).

The slight decrease in late Quaternary paleoproductivity from west to east can be a signal of nutrient decrease towards the Eastern Mediterranean

Two sites reflect an increase in paleoproductivity from the late Quaternary to early Quaternary and Pliocene.

In all but three units, the benthic foraminifer numbers and related paleoproductivity values are higher before than after sapropel deposition (Figs. 3I-6I), as are accumulation rates of echinoids, ostracods, and molluscs at Site 966 (Fig. 6F; at the sites from greater water depths accumulation rates of the latter organisms are factor 10 lower and statistically not significant). It might be concluded that productivity and related benthic numbers increased until a threshold value was reached, and anoxia started. Benthic numbers dropped to zero. When productivity decreased, anoxia ceased, and benthos reappeared at the seafloor. Radiolarian occurrences only in sapropels (at Sites 964 and 967) are in favor of higher productivity during sapropel deposition, although dissolution of silica had altered the original signal (Schrader and Matherne, 1981).

Nolet and Corliss (1990) describe similar distributions of benthic foraminifer numbers for Sapropel S5 (125-116 k.y.), where 5-10 cm below the sapropel, benthic foraminifer numbers show a maximum. But their conclusion differs from that presented here. They conclude that productivity had been increased, but it could not be the critical factor causing anoxia, because higher benthic foraminifer numbers are not associated with increased organic carbon values.

This hypothesis of gradually increasing paleoproductivity leading to anoxia when a threshold is attained is comparable to that presented by Castradori (1993), Emeis et al. (1991), and van Os et al. (1994).

Accumulation rates of sand-sized terrigenous matter can give a hint as to one factor contributing to the observed productivity variations. At Sites 966, 967, and the Quaternary sediments at Site 969, which are all sites that receive terrigenous detritus mainly from Africa, maxima of $>63-\mu \mathrm{m}$-sized terrigenous matter are at the boundary between oxygenated sediments and sapropels, simultaneous to paleoproductivity maxima. Accumulation rates of terrigenous matter are very low in the sapropels and increase slightly above. The sand-sized terrigenous matter is the coarsest part of total terrigenous input, but it is assumed that fine fractions vary in parallel. Grain-size data of the fine-terrigenous fraction point to increased runoff during sapropel deposition.

Sapropel deposition (after Rossignol-Strick, 1983) is related to an increase in summer insolation over the northern hemisphere, intensification of Indian-summer monsoons, and high fresh-water discharge of the Nile River, as well as to increased Eurasian river discharge (Shaw and Evans, 1984; Rossignol-Strick, 1983). The present results are in agreement with these interpretations and with analyses of organic facies by Mukhopadhyay (1990) and with analyses of a Pliocene-age sapropel by Rohling et al. (1993). It can be concluded that increased river discharge contributed to nutrient increase, which is reflected in increasing productivity. Sites 966 and 967, which are north of the Nile delta, show an increase in coarse-terrigenous supply before sapropel formation. When productivity reached a certain threshold value, probably combined with a change in deep-water ventilation or development of an oxygen minimum zone (Emeis et al., Chap. 26, this volume), anoxia started. Some thousand years later, terrigenous input, and thus nutrient release, decreased as did productivity until anoxia ceased. In the post-younger Dryas Sapropel S1 the same finding is described by Troelstra and van Hinte (1995): in- 
creased Nile discharge before sapropel formation, and reduction in Nile influence at the end. The Pliocene-age sapropels at Site 969, which are mostly influenced by eolian input from Italy, and the Quaternary-age sapropels at Site 964 probably had different triggering mechanisms for sapropel deposition, because here terrigenous input was highest not before, but during, sapropel deposition, as are silt grain sizes.

\section{Carbonate Dissolution}

Carbonate dissolution in the oceans varies as a function of water depth, bottom-water chemistry, and surface-water productivity. The decay of organic matter sinking down from surface waters and the "respiratory calcite dissolution" (Archer and Maier-Reimer, 1994) lead to carbonate dissolution above the lysocline (Emerson and Bender, 1981). With increasing paleoproductivity and increasing organic carbon to calcium carbonate rain ratio (Emerson and Archer, 1990), dissolution becomes stronger (Diester-Haass, 1995) as long as oxygen is available at the seafloor. In anoxic sediments, sulfate reduction increases alkalinity, and this can lead to calcium carbonate fossils being excellently preserved (Berger and Soutar, 1970). At the sites investigated, different water depths do not exert a major influence on carbonate dissolution: Sites 969, 964, and 967 have comparable and very low fragmentation values of planktic foraminifers, despite different depths (Figs. 3H-5H). Fragmentation is stronger only at Site 966 because of much higher productivity over this seamount (Fig. 6H).

Carbonate dissolution controls accumulation rates of planktic foraminifers. These are highest in the best preserved units and decrease in general with increasing dissolution.

Three types of response of carbonate dissolution to sapropel deposition can be differentiated.

1. Excellent carbonate preservation of planktic foraminifers and even aragonitic shells of pteropods and highest accumulation rates of planktic foraminifers in the late Quaternary sapropel of Site 966, due to anoxia and no "burning down" phenomena (Higgs et al., 1994; Rohling, 1994) in the uppermost part of the sapropel.

2. Excellent carbonate preservation at the bottom of the sapropel, with high accumulation rates of planktic foraminifers and preservation of pteropods, and with an increase in dissolution towards the top of the sapropel and the disappearance of pteropods (late Quaternary of Site 964 and 967, early Pliocene of Site 966). This phenomenon is explained by downward progressing oxygenation (Higgs et al., 1994; Rohling, 1994) and following bacterial respiratory activity after return to oxygenated conditions.

3. In sapropels that have been bioturbated after return to oxygenated conditions (marked "b" in Figs, 3-6) carbonate dissolution is higher or as high as in overlying and underlying oxygenated sediments (Figs. 3H-6H).

The Quaternary-age sapropels investigated are not bioturbated, whereas in the Pliocene age, the burrowing of sapropels destroyed the sapropel signals. One factor might be the observed higher Pliocene paleoproductivity when compared to the Quaternary: higher export productivity in the Pliocene allowed higher density of burrowing benthos after sapropel deposition.

\section{CONCLUSION}

The absence of any clay mineral specific to the sapropels and the presence of the same clay species in the sapropels and adjacent, oxi- dized sediments indicates the absence of significant diagenetic alteration and modification of the sources of terrigenous particles during development of the sapropels.

Relative importance of the clay species vary according to the location of the sites: chlorite, illite, and random mixed-layer clays from southern Europe dominate in the Ionian Basin; palygorskite and sepiolite from North Africa characterize the sediments of the Mediterranean Ridge; and smectite from the Nile River dominates on the Eratosthenes Seamount.

The abundance of some clay minerals vary according to the age of the sediment: kaolinite and smectite increase in lower Pliocene sediments, indicating intensified chemical weathering and increased terrigenous supply from the Nile during this warm interval.

The clay-mineral association shows minor but diversified changes in the sapropels. Chlorite, illite, and random mixed-layer clays, eroded from Southern Europe by precipitation and runoff increase in most sapropels at all sites. Increased amounts of palygorskite and sepiolite from North Africa and the Middle East are carried by intensified atmospheric circulation to the Mediterranean Ridge, and sometimes to the Eratosthenes Seamount. On the Eratosthenes Seamount, particles from the terrigenous load of the Nile (smectite) increase in some sapropels that are of early Pliocene age principally, but most sapropels of early Pliocene age show increased contents of kaolinite and smectite indicative of intensified chemical weathering on land (i.e., higher temperatures and/or precipitation).

All sapropels are characterized by increased silt-sized and decreased clay-sized particles and a higher mode of the grain-size distribution, indicating higher energy during deposition of sapropels.

At intermediate water depth on the Eratosthenes Seamount, an increasing trend in the abundance of smectite begins in the sapropels and persists in the oxidized overlying sediments. This may indicate evolving production and circulation of Levantine intermediate water, marked by the terrigenous load of the Nile.

Export productivity has been calculated from benthic foraminifer accumulation rates. It is higher before sapropel deposition and might suggest that productivity increased until a threshold value was attained and anoxia started. Decrease of productivity below a certain threshold contributed to restore oxic conditions, whereas deep-water exchange is probably the most important factor for the return to oxic conditions (Emeis et al., Chap. 26, this volume).

Paleoproductivity decreases from west to east during deposition of late Quaternary oxygenated sediments. It is higher in the Pliocene than in the Quaternary.

The coarse-grained terrigenous particles $(>63 \mu \mathrm{m})$ have highest accumulation rates before sapropel deposition at the sites north of the Nile delta, an observation that suggests an increase in river-born nutrient supply, which is supposed to have stimulated productivity. Carbonate preservation is excellent in the nonbioturbated sapropels, with preservation even of aragonitic pteropod shells. In some sapropels, carbonate preservation is excellent at the bottom and decreases toward the top because of "burning down" phenomena. Pliocene sapropels are bioturbated because of higher Pliocene export productivity. Here carbonate dissolution is as strong as in surrounding oxygenated sediments.

Intensified precipitation and circulation and an associated increase in productivity are compatible with sapropel occurrence during minima of precession, periods of high meridional gradient of insolation, and thermal exchanges.

\section{ACKNOWLEDGMENTS}

We thank the Ocean Drilling Program and Shipboard Scientific Party for providing samples; K. Emeis for help, discussions and review of the manuscript; C. Schramm (Saarbrücken) for sample preparation; C. Stuffer (Saarbrïcken) for computer generated figures; P. 
Recourt and D. Malengros for technical help; and J. Carpentier for photos.

\section{REFERENCES}

Aksu, A.E., Yasar, D., and Mudie, P.J., 1995. Paleoclimatic and paleoceanographic conditions leading to development of sapropel layer S1 in the Aegean Sea. Palaeogeogr., Palaeoclimatol., Palaeoecol., 116:71-101.

Archer, D.E., and Maier-Reimer, E., 1994. Effect of deep-sea sedimentary calcite preservation on atmospheric $\mathrm{CO}_{2}$ concentration. Nature, 367:260263.

Berger, W.H., 1976. Biogenous deep-sea sediments: production, preservation, and interpretation. In Riley, J.P., and Chester, R. (Eds.), Chemical Oceanography (Vol. 5): London (Academic Press), 265-388.

Berger, W.H., and Soutar, A., 1970. Preservation of plankton shells in an anaerobic basin off California. Geol. Soc. Am. Bull., 81:275-282.

Béthoux, J.-P., 1989. Oxygen consumption, new production, vertical advection and environmental evolution of the Mediterranean Sea. Deep-Sea Res., 36:769-781.

Castradori, D., 1993. Calcareous nannofossils and the origin of eastern Mediterranean sapropels. Paleoceanography, 8:459-471.

Chamley, H., 1971. Recherches sur la sedimentation argileuse en Méditerranée. Sci. Geol. Mem., 35.

, 1989. Clay Sedimentology: Berlin (Springer-Verlag).

Cita, M.B., Vergnaud-Grazzini, C., Robert, C., Chamley, H., Ciaranfi, N., and D'Onofrio, S., 1977. Paleoclimatic record of a long deep sea core from the eastern Mediterranean. Quat. Res., 8:205-235.

Crowley, T.J., and North, G.R., 1991. Paleoclimatology: Oxford Monographs on Geology and Geophysics: New York (Oxford Univ. Press).

Diester-Haass, L., 1995. Middle Eocene to early Oligocene paleoceanography of the Antarctic Ocean (Maud Rise, ODP Leg 13, Site 689): change from a low to a high productivity ocean. Palaeogeogr., Palaeoclimatol., Palaeoecol., 113:311-334.

Diester-Haass, L., and Zahn, R., 1996. The Eocene-Oligocene transition in the Southern Ocean: history of water masses, circulation, and biological productivity inferred from high resolution records of stable isotopes and benthic foraminiferal abundances (ODP Site 689). Geology, 26:163-166.

Dominik, J., and Stoffers, P., 1979. The influence of late Quaternary stagnations on clay sedimentation in the Eastern Mediterranean Sea. Geol. Rundsch., 68:302-317.

Emeis, K.-C., Camerlenghi, A., McKenzie, J.A., Rio, D., and Sprovieri, R., 1991. The occurrence and significance of Pleistocene and Upper Pliocene sapropels in the Tyrrhenian Sea. Mar. Geol., 100:155-182.

Emeis, K.-C., Robertson, A.H.F., Richter, C., et al., 1996. Proc. ODP, Init Repts., 160: College Station, TX (Ocean Drilling Program).

Emeis, K.-C., and Shipboard Scientific Party, 1996. Paleoceanography and sapropel introduction. In Emeis, K.-C., Robertson, A.H.F., Richter, C., et al., Proc. ODP, Init. Repts., 160: College Station, TX (Ocean Drilling Program), 21-28.

Emerson, S.R., and Archer, D., 1990. Calcium carbonate preservation in the ocean. Philos. Trans. R. Soc. London A, 331:29-40.

Emerson, S.R., and Bender, M.L., 1981. Carbon fluxes at the sediment-water interface of the deep-sea: calcium carbonate preservation. J. Mar. Res., 39:139-162.

Fagel, N., Hillaire-Marcel, C., and Robert, C., 1997. Changes in the Western Boundary Undercurrent outflow since the Last Glacial Maximum, from smectite/illite ratios in deep Labrador Sea sediments. Paleoceanography, 12:79-96.

Herguera, J.C., and Berger, W.H., 1991. Paleoproductivity: glacial to postglacial change in the western equatorial Pacific, from benthic foraminifera. Geology, 19:1173-1176.

Higgs, N.C., Thompson, J., Wilson, T.R.S., and Croudace, I.W., 1994. Modification and complete removal of eastern Mediterranean sapropels by postdepositional oxidation. Geology, 22:423-426.

Hilgen, F.J., Lourens, L.J., Berger, A., and Loutre, M.F., 1993. Evaluation of the astronomically calibrated time-scale for the late Pliocene and earliest Pleistocene. Paleoceanography, 8:549-565.
Malanotte-Rizzoli, P., and Hecht, A., 1988. Large-scale properties of the eastern Mediterranean: a review. Oceanol. Acta, 11:323-335.

McCave, I.N., Manighetti, B., and Beveridge, N.A.S., 1995. Circulation in the glacial North Atlantic inferred from grain-size measurements. Nature, 374:149-151.

Millot, G., 1970. Geology of Clays: Berlin (Springer).

Millot, G., Nahon, D., Paquet, H., Ruellan, A., and Tardy, M., 1977. L'épigénie calcaire des roches silicatées dans les encroûtements carbonatés en pays subaride, Anti-Atlas (Maroc). Sci. Geol. Bull., 30:129-152.

Mukhopadhyay, P.K., 1990. Organic facies and maturation of sediments from the Tyrrhenian Sea, Ocean Drilling Program, Leg 107. In Kastens, K.A., Mascle, J., et al., Proc. ODP, Sci. Results, 107: College Station, TX (Ocean Drilling Program), 579-590.

Nolet, G.J., and Corliss, B.H., 1990. Benthic foraminiferal evidence for reduced deep-water circulation during sapropel deposition in the Eastern Mediterranean. Mar. Geol., 94:109-130.

Robert, C., and Chamley, H., 1987. Cenozoic evolution of continental humidity and paleoenvironment, deduced from the kaolinite content of oceanic sediments. Palaeogeogr., Palaeoecol., Palaeoclimatol., 60:171-187.

Rohling, E.J., 1994. Review and new aspects concerning the formation of eastern Mediterranean sapropels. Mar. Geol., 122:1-28.

Rohling, E.J., Vergnaud-Grazzini, C., and Zaalberg, R., 1993. Temporary repopulation by low-oxygen tolerant benthic foraminifera within an Upper Pliocene sapropel: evidence for the role of oxygen depletion in the formation of sapropels. Mar. Micropaleontol., 21:207-219.

Rossignol-Strick, M., 1983. African monsoons: an immediate climate response to orbital insolation. Nature, 304:46-49.

, 1985. Mediterranean Quaternary sapropels, an immediate response of the African Monsoon to variation of insolation. Palaeogeogr., Palaeoclimatol., Palaeoecol., 49:237-263.

Rossignol-Strick, M., Nesteroff, W., Olive, P., and Vergnaud-Grazzini, C., 1982. After the deluge: Mediterranean stagnation and sapropel formation. Nature, 295:105-110.

Sarmiento, J., Herbert, T., and Toggweiler, J., 1988. Mediterranean nutrient balance and episodes of anoxia. Global Biogeochem. Cycles, 2:427-444.

Schrader, H., and Matherne, A., 1981. Sapropel formation in the eastern Mediterranean Sea: Evidence from preserved opal assemblages. Micropaleontology, 27:191-203.

Shaw, H.F., and Evans, G., 1984. The nature, distribution and origin of a sapropelic layer in sediments of the Cilicia Basin, northeastern Mediterranean. Mar. Geol., 61:1-12.

Sigl, W., Chamley, H., Fabricius, F., Giroud d'Argoud, G., and Mueller, J., 1978. Sedimentology and environmental conditions of sapropels. In Hsü, K.J., Montadert, L., et a., Init. Repts. DSDP, 42: Washington (U.S. Govt. Printing Office), 445-465.

Tomadin, L., Lenaz, R., Landuzzi, V., Mazzucottelli, A., and Vannucci, R., 1984. On wind-blown dusts over the central Mediterranean. Oceanol. Acta, 7:13-24.

Troelstra, S.R, and van Hinte, J.E., 1995. The Younger Dryas-Sapropel S1 connection in the Mediterranean Sea (extended Abstract). Geol. Mijnbouw, 74:275-280.

Van Os, B.J.H., Lourens, L.J., Hilgen, F.J., De Lange, G.J., and Beaufort, L., 1994. The formation of Pliocene sapropels and carbonate cycles in the Mediterranean: diagenesis, dilution, and productivity. Paleoceanography, 9:601-617.

Venkatarathnam, K., and Ryan, W.B.F., 1971. Dispersal patterns of clay minerals in the sediments of the Eastern Mediterranean Sea. Mar. Geol., 11:261-282.

Weaver, C.E., 1989. Clays, Muds, and Shales: New York (Elsevier), Dev. in Sedimentol. Ser., 44.

Date of initial receipt: 27 January 1997

Date of acceptance: 22 June 1997

Ms 160SR-008 


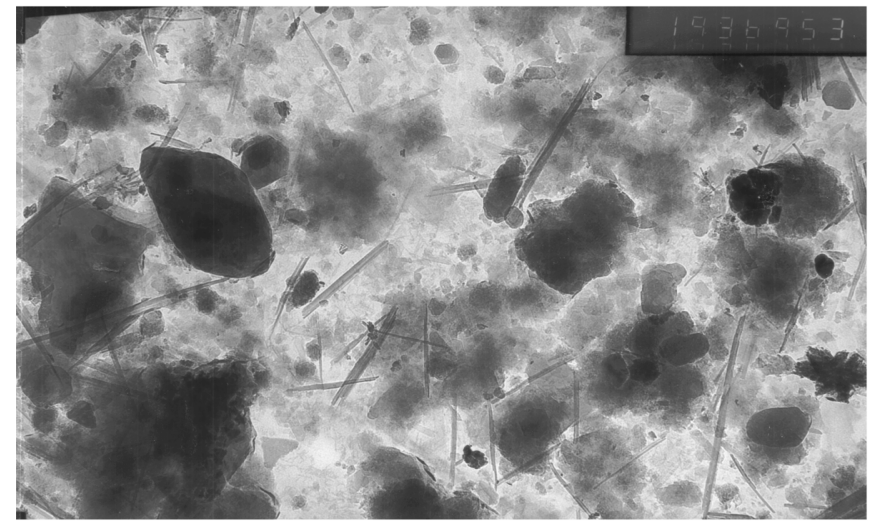

1

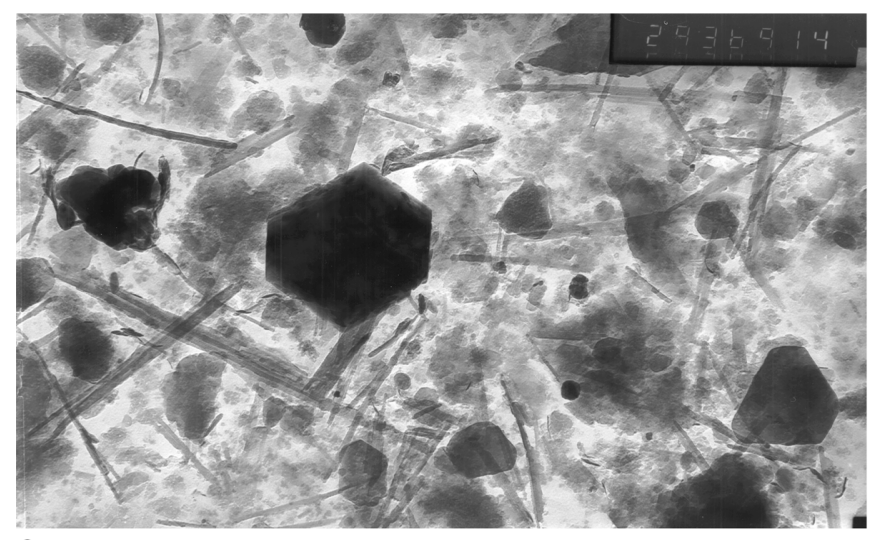

3

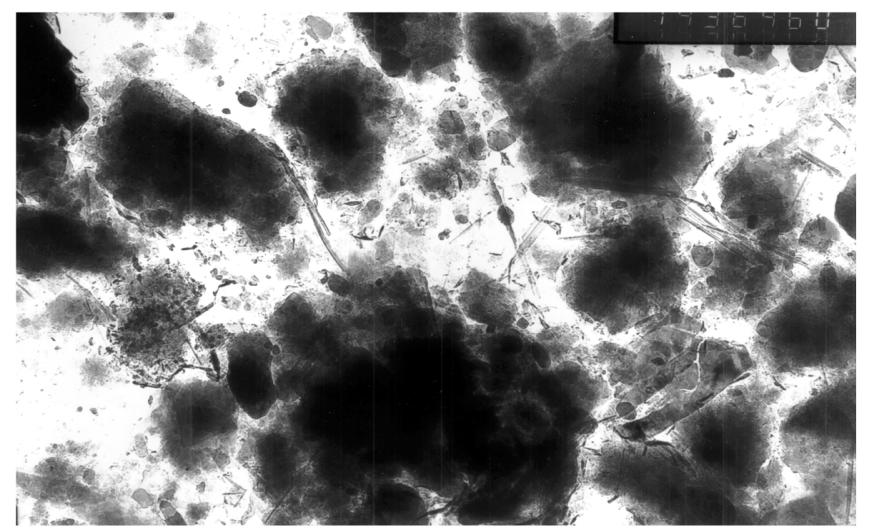

2

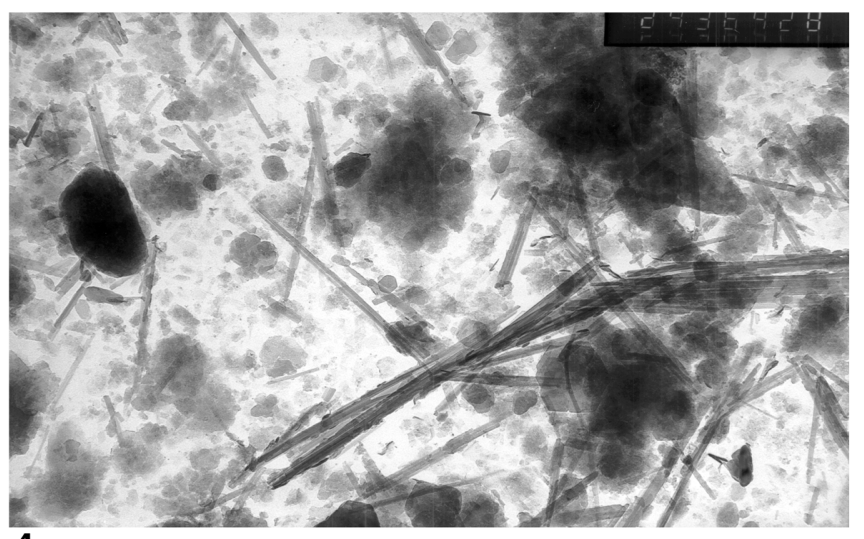

4

Plate 1. Ionian Basin: 1. Sample 160-964A-2H-1, 85 cm, 7.65-m sub-bottom depth, oxidized sediment, 12,825×. 2. Sample 160-964A-2H-1, 105 cm, 7.75-m sub-bottom depth, sapropel (1.3\% organic carbon), 9,450×. Note better contours of particles in oxidized sediment, greater abundance of fleecy particles in sapropel, and presence of fibers (palygorskite, sepiolite) in both samples. Mediterranean Ridge: 3. Sample 160-969A-7H-1, $39 \mathrm{~cm}, 55.59-\mathrm{m}$ sub-bottom depth, oxidized sediment, 19,575×. 4. Sample 160-969A-7H-1, $52 \mathrm{~cm}$, 55.72-m sub-bottom depth, sapropel (5.3\% organic carbon), 19,575×. Note shorter individual fibers in sapropel, together with bundles of fibers, and greater abundance of subrounded particles in sapropel. 


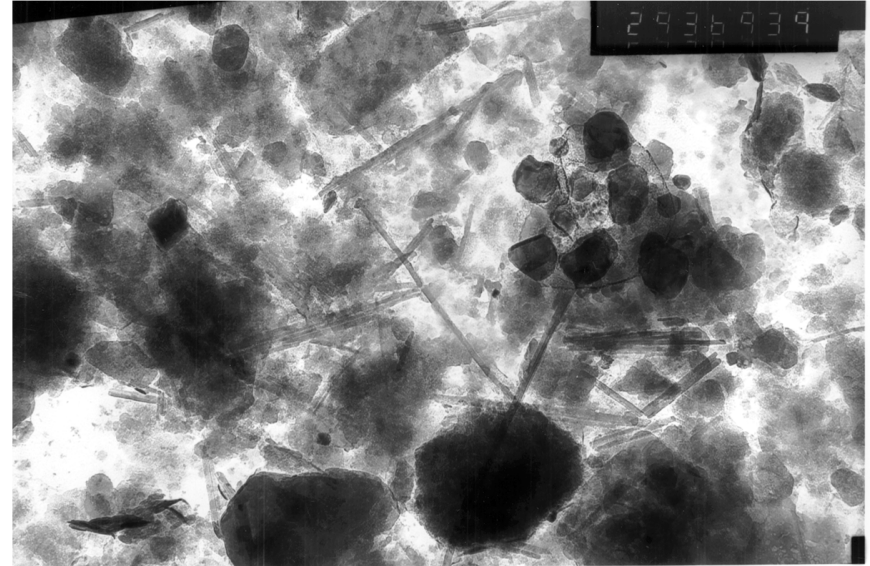

1

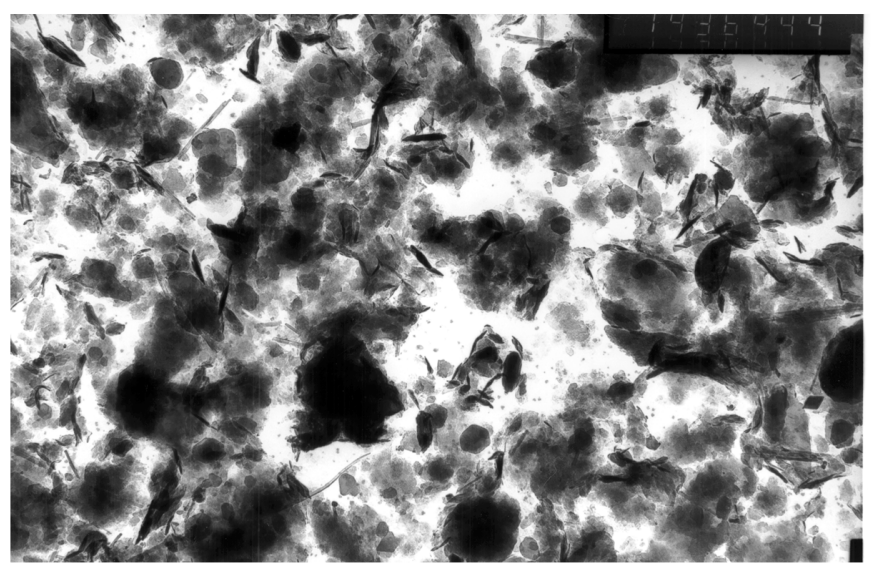

3

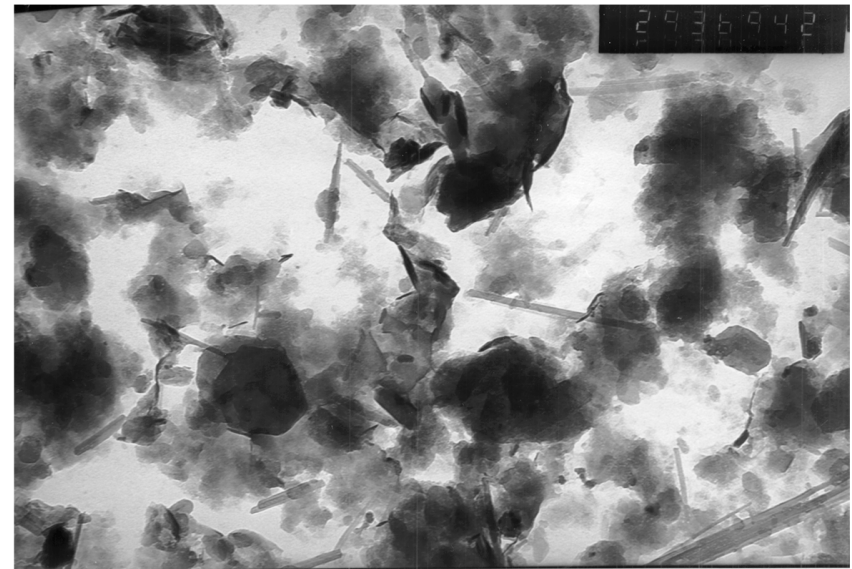

2

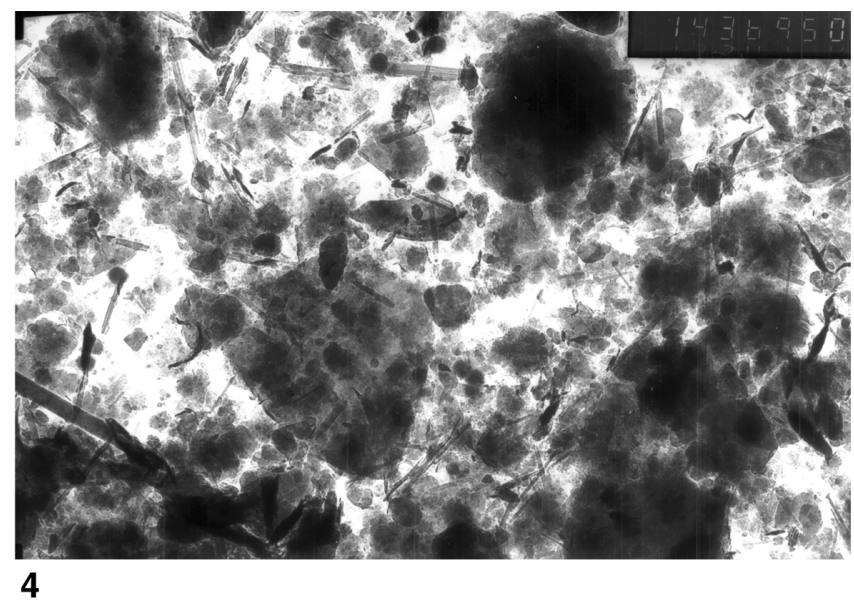

Plate 2. Eratosthenes Seamount: 1. Sample 160-966C-7H-5, $9 \mathrm{~cm}, 63.09-\mathrm{m}$ sub-bottom depth, oxidized sediment, 19,575×. 2. Sample 160-966C-7H-5, 18 cm, 63.18-m sub-bottom depth, sapropel (2\% organic carbon), 19,575×. 3. Sample 160-966C-7H-5, $48 \mathrm{~cm}, 63.48-\mathrm{m}$ sub-bottom depth, sapropel (1\% organic carbon), 9,450×. 4. Sample 160-966C-7H-5, $68 \mathrm{~cm}, 63.68-\mathrm{m}$ sub-bottom depth, oxidized sediment, 9,450×. Note greater abundance of fibers in oxidized sediments, presence of shorter fibers, and some bundles of fibers in sapropels. There is also a greater abundance of opaque particles with neat contours in the oxidized sediments. 